\title{
The novel compound PBT434 prevents iron mediated neurodegeneration and alpha-synuclein toxicity in multiple models of Parkinson's disease
}

\author{
David I. Finkelstein ${ }^{1 *}$ D, Jessica L. Billings ${ }^{1}$, Paul A. Adlard ${ }^{1}$, Scott Ayton ${ }^{1}$, Amelia Sedjahtera ${ }^{1}$, Colin L. Masters ${ }^{1}$, \\ Simon Wilkins' ${ }^{1}$, David M. Shackleford ${ }^{3}$, Susan A. Charman ${ }^{3}$, Wojciech Bal ${ }^{4}$, Izabela A Zawisza ${ }^{4}$, Ewa Kurowska ${ }^{4}$, \\ Andrew L. Gundlach', Sheri Ma', Ashley I. Bush', Dominic J. Hare ${ }^{1,5}$, Philip A. Doble ${ }^{5}$, Simon Crawford ${ }^{6}$, \\ Elisabeth CL. Gautier', Jack Parsons², Penny Huggins ${ }^{2}$, Kevin J. Barnham ${ }^{1,7}$ and Robert A. Cherny ${ }^{1,2^{*}}$
}

\begin{abstract}
Elevated iron in the SNpc may play a key role in Parkinson's disease (PD) neurodegeneration since drug candidates with high iron affinity rescue PD animal models, and one candidate, deferirpone, has shown efficacy recently in a phase two clinical trial. However, strong iron chelators may perturb essential iron metabolism, and it is not yet known whether the damage associated with iron is mediated by a tightly bound (eg ferritin) or lower-affinity, labile, iron pool. Here we report the preclinical characterization of PBT434, a novel quinazolinone compound bearing a moderate affinity metal-binding motif, which is in development for Parkinsonian conditions. In vitro, PBT434 was far less potent than deferiprone or deferoxamine at lowering cellular iron levels, yet was found to inhibit iron-mediated redox activity and iron-mediated aggregation of a-synuclein, a protein that aggregates in the neuropathology. In vivo, PBT434 did not deplete tissue iron stores in normal rodents, yet prevented loss of substantia nigra pars compacta neurons $(\mathrm{SNpc})$, lowered nigral a-synuclein accumulation, and rescued motor performance in mice exposed to the Parkinsonian toxins 6-OHDA and MPTP, and in a transgenic animal model (hA53T a-synuclein) of PD. These improvements were associated with reduced markers of oxidative damage, and increased levels of ferroportin (an iron exporter) and DJ-1. We conclude that compounds designed to target a pool of pathological iron that is not held in high-affinity complexes in the tissue can maintain the survival of SNpc neurons and could be disease-modifying in PD.
\end{abstract}

Keywords: Synucleinopathy, Drug development, Chelation, Oxidative stress, Neuroprotection

\section{Introduction}

Idiopathic Parkinson's disease (PD) is characterized by loss of the neurons of the substantia nigra pars compacta (SNpc) and the presence of intracellular Lewy bodies composed primarily of fibrillar deposits of the synaptic protein $\alpha$-synuclein. The physiological function of $\alpha$-synuclein is poorly understood, but genetic evidence strongly implicates this highly-expressed protein in the pathological

\footnotetext{
* Correspondence: d.finkelstein@florey.edu.au; rcherny@unimelb.edu.au ${ }^{1}$ The Florey Institute of Neuroscience and Mental Health, The University of Melbourne, Melbourne, VIC 3010, Australia

Full list of author information is available at the end of the article
}

process in PD and other movement disorders such as Multiple System Atrophy and Diffuse Lewy Body Disease, (classified as synucleinopathies).

$\alpha$-synuclein may be neurotoxic in the fibrillar state or soluble oligomeric species $[20,42]$. However, it is expressed throughout the brain, so the selective vulnerability of the SNpc in PD indicates other local factors may be involved in toxicity. This could be due to the co-localization within the SNpc of the chemical reductant dopamine (DA) with an abundance of the redox active metal iron, in addition to $\alpha$-synuclein $[41,43]$. $\alpha$-synuclein binds iron with micromolar affinity [22], and 
both iron and DA promote the aggregation of $\alpha$-synuclein and the formation of Lewy bodies [15, 16, 28, 33], and can react together to form damaging peroxides [40]. There is consistent evidence of a regional increase of iron in the SNpc of PD patients $[10,25,64]$ as well as a rapid accumulation of nigral iron in animals following intoxication with the Parkinsonian agents 6-hydroxydopamine (6-OHDA) and 1-methyl-4-phenyl-1,2,3,6-tetrahydropyridine (MPTP) $[27,70]$. Iron is needed for numerous catalytic and metabolic processes including as a cofactor for tyrosine hydroxylase $(\mathrm{TH})$, the enzyme responsible for the production of L-3,4-dihydroxyphenylalanine (L-DOPA) from tyrosine $[36,85]$. However, dysregulation of iron through aging may increase the potential for oxidative damage [11], which is exaggerated in the SNpc in PD [9].

Recently, the high affinity iron chelator deferiprone (3-Hydroxy-1,2-dimethyl-4-pyridinone) was reported to provide benefit in a phase 2 randomized clinical trial in PD patients [24]. Although deferiprone was well tolerated there remain concerns with known adverse effects of strong chelators [81]. Indeed, there is no certainty about the compartment of pathological iron in the $\mathrm{SNpc}$ that might mediate the neuropathology. Since the labile iron pool is not tightly bound, we reasoned that it might be possible to provide neuro-rescue with moderate-affinity bioavailable iron chelators. We have been developing candidate drugs for neurodegenerative diseases designed to re-establish normal metal homeostasis and abort the oligomerization of susceptible proteins caused by pathological low affinity adventitial metal ligation $[1,2,18,53,57]$. PBT434, an orally bioavailable 8-hydroxyquinazolin-4(3H)-one, binds iron sufficiently to abolish pathological reaction with $\alpha$-synuclein, but with an affinity that is designed not to disrupt physiological iron homeostasis.

We hypothesized that targeting the pathological pool of nigral iron that emerges in these models with PBT434 would preserve function and the consequent accumulation of $\alpha$-synuclein. We tested PBT434 for its ability to preserve neuronal viability and connectivity, motor function, $\alpha$-synuclein accumulation and markers of oxidative stress in three animal models of PD: the Parkinsonian toxins 6-OHDA and MPTP, and hA53T transgenic mice (which overexpress human $\alpha$-synuclein bearing the alanine to threonine mutation at position 53 , which causes familial PD).

\section{Materials and methods Potentiometry}

Potentiometric titrations of the peptides were performed on a MettlerTitrando 907/Dosino 800 titration system, using InLab 422 combined glass- $\mathrm{Ag} / \mathrm{AgCl}$ electrodes (Mettler-Toledo), which were calibrated daily by nitric acid titrations [2]. $0.1 \mathrm{M} \mathrm{NaOH}$ (carbon dioxide free) was used as titrant. Sample volumes of $1.2-1.5 \mathrm{ml}$ were used. The samples contained typically $0.8 \mathrm{mM}$ PBT-434, dissolved in $4 \mathrm{mM} \mathrm{HNO} / 96 \mathrm{mM}$ KNO3. The Fe (II) and Fe (III) complex formation was studied using a 2.54-fold excess of the compound over the metal ion, added as nitrate. All experiments were performed under argon at $25{ }^{\circ} \mathrm{C}$, in the $\mathrm{pH}$ range of 2.3 to 12.2 . The collected data were analyzed using the HYPERQUAD program [1]. Three to five titrations were included simultaneously into calculations, separately for protonation, Fe (II) and Fe (III) complexation.

The UV-visible spectra were recorded at $25{ }^{\circ} \mathrm{C}$ on a Cary 50 or a Perkin Elmer spectrophotometer, over the spectral range of $230-800 \mathrm{~nm}$. The optical path for all experiments was $1 \mathrm{~cm}$. The samples containing PBT-434 alone or with $\mathrm{Fe}$ (II), $\mathrm{Fe}$ (III), $\mathrm{Cu}$ (II) or $\mathrm{Zn}$ (II) ions were titrated with $\mathrm{NaOH}$ in the $\mathrm{pH}$ range of $2.0-12.0$, by careful manual additions of very small amounts of the concentrated base solution. For Fe (III) and Fe (II) the PBT-434 concentration used was $0.1 \mathrm{mM}$, and the ligand-to-metal ratio was $4: 1$, to keep in line with conditions that delivered good potentiometic titrations. For $\mathrm{Cu}$ (II) the PBT434 concentration used was $0.1 \mathrm{mM}$, and the ligand-to-metal ratios used varied between 1:1 and 4:1. For $\mathrm{Zn}$ (II) spectroscopic titrations were performed at a lower concentration of $0.04 \mathrm{mM} \mathrm{PBT434}$ and $0.02 \mathrm{mM}$ Zn (II) to avoid precipitation. The Fe (II) samples were prepared under nitrogen, in a Coy glove box, and transferred to the spectrophotometer $[34,46]$.

\section{Inhibition of metal/dopamine mediated $\mathrm{H}_{2} \mathrm{O}_{2}$ generation} This technique, adapted from established protocols [74], is a dicholorofluoroscein (DCF)-based fluorometric assay that evaluates the ability of a test compound to inhibit $\mathrm{H}_{2} \mathrm{O}_{2}$ generated by redox active metals in the presence of a reducing agent.

\section{a-synuclein aggregation assay}

Each batch of recombinant $\alpha$ synuclein that was synthesised underwent protein sequencing and mass spectrometry to ensure purity at the Monash Protein Production Unit (Monash University, Australia). The lyophilised purified WT recombinant $\alpha$ synuclein was reconstituted with Tris Buffer Saline (TBS) pH 7.4. Pooled aliquots were spun at $100,000 \mathrm{~g}$ for $30 \mathrm{mins}$ at $4^{\circ}$ to remove preformed aggregates/seeds. The supernant containing the monomeric form was collected and used in the assay. The protein concentration was determined using BCA method Iron Nitrate was weighed and dissolved in TBS solution. PBT434 was dissolved in 100\% DMSO, then diluted to stock solution using milliQ water. To each tube, TBS, Fe, Compound/Veh then $\alpha$ synuclein was added in sequence with equal concentrations. The final concentration of $\alpha$ synuclein, Fe and compound was $186.6 \mu \mathrm{M}$. 
Once all solutions were in the tubes, samples were vortex for $2 \mathrm{~s}$ before plating up. Samples were assayed in the presence of ThT $(20 \mu \mathrm{M})$. The assay was read in a Perkin-Elmer Enspire multi-mode plate reader set at $37^{\circ}$, reading every $30 \mathrm{mins}(1800 \mathrm{~s})$, shaking at $800 \mathrm{rpm}$ (1800 Seconds) between each read up to $42 \mathrm{~h}$. ThT fluorescence intensity was measured over time at wavelengths 450 emission and $485 \mathrm{~nm}$ excitation. The RFU values were normalised to TBS ThT blank wells and were plotted over time. The lag-time and the maximal relative fluorescent units (RFU) were reported as a measure of kinetic profiling of compounds. These were calculated based on a 4-point parameter sigmoidal curve (plotted in Sigmaplot V12.5).

\section{Preparation of a-synuclein fibril samples for transmission electron microscopy}

Forty-two hours after initiating the $\alpha$-synuclein reaction 20uL droplets were adsorbed onto formvar-coated copper grids for 30 mins. After incubating the excess solution was blotted away and the samples on grids were stained with $1 \%$ uranyl acetate for $30 \mathrm{~s}$. The excess stain was then blotted away and the grids allowed to dry at room temperature overnight. The samples on grids were viewed in an FEI Tecnai Spirit transmission electron microscope at $120 \mathrm{kV}$. Images were captured with a Gatan Eagle digital camera at a resolution of $2 \mathrm{~K} \times 2 \mathrm{~K}$ pixels.

\section{Iron efflux assay}

M17 neuroblastoma cells were detached from two $175 \mathrm{~cm}$ flasks and re-suspended in $100 \mathrm{ml}$ of Optimem growth medium. Cells were transferred to poly-d-lysine coated, 12-well plates and allowed to recuperate for $24 \mathrm{~h} .50 \mu \mathrm{l}$ of ${ }^{59} \mathrm{Fe}$ was added to $800 \mu \mathrm{l}$ of Optimem (without serum) for overnight incubation. Cells were then washed in HBSS (buffered saline) $\times 3$, then $500 \mu \mathrm{l}$ of HBSS was added with either no drug $1 \mu \mathrm{M}, 10 \mu \mathrm{M}, 20 \mu \mathrm{M}$ of PBT434 or deferiprone. Experiment was terminated after $3 \mathrm{~h}$. Medium was removed and radiation measured using a gamma counter.

\section{Mice}

Male C57BL/6 J mice aged 12 weeks and weighing $\approx 25 \mathrm{~g}$ were used for the 6-OHDA and MPTP studies (Animal Resources Centre; Western Australia). The hA53T Tg mice were bred in-house (Jax Stock No: 004479; B6;C3-Tg (Prnp-SNCA*A53T)83Vle/J; A53T $\alpha$-synuclein transgenic line M83). PBT434 (at $30 \mathrm{mg} / \mathrm{kg} /$ day) was delivered either by oral gavage or by being mixed into rodent chow (Glen Forrest Stockfeeds, Western Australia; spiked at $0.25 \mathrm{~g} / \mathrm{kg}$ food; 20 days days of treatment for the MPTP; 18 days of treatment 6-OHDA; four months of daily treatment for the hA53T Tg mice).

\section{6-OHDA intoxication model}

Mice anesthetized with $2.5-3 \%$ isoflurane were placed into a stereotaxic apparatus and $3.0 \mu \mathrm{g}$ of 6-OHDA was injected into the right $\mathrm{SNpc}$, as described in [77]. Amphetamine induced $(5 \mathrm{mg} / \mathrm{kg}$ ) rotational behavior was measured three days after 6-OHDA lesion using an automated Rotacounter system (Columbus Instruments, Columbus, OH, USA). Robust rotational behavior has been observed as early as one-day post-lesion [82, 87]. Only mice that exhibited rotations at day 3 between 200 and 450 times per hour were included in the trial. Mice were then randomly assigned to the PBT434 treatment group or sham-vehicle (VEH) treatment group. The PBT434 treatment group was gavaged at $30 \mathrm{mg} / \mathrm{kg} / \mathrm{day}$, commencing 3 days following induction of lesion. Experimenters were blinded to the assignment of treatments for each of the groups. Mice were retested and then culled twenty-one days post 6-OHDA lesion.

\section{MPTP model}

Mice were administered an acute dosing regimen of four injections of MPTP (Sigma, USA) two hours apart $[4,5,61]$. Each experimental trial contained MPTP lesioned animals that were randomly subdivided into a sham treated group (vehicle alone) and drug treatment group (30 mg/kg/day PBT434, commencing $24 \mathrm{~h}$ after MPTP until culled at day 21). Experimenters were blinded to the assignment of treatments for each of the groups. In one group of animals the mice were treated with analog of PBT434 (PBT434-met $30 \mathrm{mg} / \mathrm{kg} /$ day) which does not have the ability to bind metals as a control.

The pole test was used to measure motor co-ordination and performance at twenty days post MPTP injection $[32,67,73]$. The mice were assessed on their ability to rotate their heads and their bodies $180^{\circ}$ to position themselves in order to turn down descend down the pole to the home cage [44]. The fastest times obtained from the five trials were used as the value for turn time; measured in seconds. Experimenters were blinded to the treatments of each of the groups.

\section{Hindlimb clasping and motor activity}

Briefly, mice were suspended by the base of the tail and their behaviors were recorded for $30 \mathrm{~s}[62,78]$. Spontaneous motor activity was measured in the hA53T $\alpha$ - synuclein mouse using an open field photo-beam activity System (Truscan 2.0, Coulbourn Instruments, USA) [61].

\section{Tissue preparation}

At the completion of a trial, mice were killed with an overdose of anesthetic, perfused with phosphate buffered saline (PBS) pH 7.4 and tissues collected [61]. The blood samples were analyzed by a veterinary pathology service (Gribbles Veterinary Australia, accreditation to ISO/IEC 
17025 conferred by the National Association of Testing Authorities and certification to AS/NZS 9001: 2008 conferred by Lloyd's Register Quality Assurance).

\section{Western blots}

Western blot was used to investigate protein expression of human $\alpha$ - synuclein in the hA53T mouse (LB509; 1:10,000; Abcam, USA), the expression of endogenous $\alpha$ - synuclein (97/8 1;10,000; a gift from Dr. Janetta Culvenor, University of Melbourne, Australia) or human, tyrosine hydroxylase ( $\mathrm{TH}, 1: 10,000$; Millipore, USA), Protein deglycase, also known as Parkinson disease protein 7 (DJ1, Polyclonal, 2134, CST, Boston, USA), Ferroportin-1 (1:1000; Santa Cruz, USA), Anti-synaptophysin, clone SY38 (1:10,000; Millipore, USA), Samples were homogenised in PBS buffer (PBS, Invitrogen, EDTA-free Protease cocktail inhibitor, Roche, USA) with $11.02 \mathrm{mg} / \mathrm{mL}$ BHT (Sigma-Aldrich, USA) in acetonitrile (Sigma-Aldrich, USA) solution using sonication (20\% amplitude, pulses 1$2 \mathrm{~s}$ while on ice). The crude homogenate was spun on a benchtop centrifuge for 10 mins $4{ }^{\circ} \mathrm{C}$. Homogenate was assayed for protein (Thermo Scientific Pierce BCA Protein Assay Kit) and between 5 and $10 \mu \mathrm{g}$ of protein loaded onto NuPage Novex bis-tris 4-12\% 26 well gels (Invitrogen, USA). Total protein was measured on the membrane, with a ponceau stain $(5 \mathrm{~min}$ at room temperature $(0.1 \%$ ready se stain, Sigma-Aldrich, catalogue \# P7170). Excess stain was washed from the membrane before exposing. The ponceau stain was used to normalise the protein of interest against total protein (loading control). The membrane was imaged using a LAS-3000 [1, 61].

\section{a -synuclein solubility analysis}

Western blot for $\alpha$ - synuclein. Tissue samples were collected, frozen, and stored at $-80{ }^{\circ} \mathrm{C}$ for later use. Brain homogenates were prepared by sequential extraction, with the 5\% SDS soluble and $8 \mathrm{M}$ urea soluble fractions examined by Western blot. Protein concentrations of the initial brain homogenates were estimated using an assay for bicinchoninic acid (BCA, Pierce Protein Assay Kit, ThermoFisher Scientific, U.S.A.). Western blots were probed with the $\alpha$ - synuclein antibody LB509 (Abcam, USA).

\section{8-isoprostane ELISA}

Dissected SN samples were collected, snap frozen and stored at $-80^{\circ} \mathrm{C}$ until analysis. The tissue homogenates were analysed in the competitive ELISA as per the manufactures instructions (Cayman Chemicals).

\section{Metal analysis}

Iron imaging of selected region (Substantia nigra; both pars compacta and pars reticulata) was performed on the $30 \mu \mathrm{m}$ cryostat sections using Laser ablation-inductively coupled plasma-mass spectrometry (LA-ICPMS) on a New Wave Research UP213 laser ablation unit (Kennelec Scientific, Australia) coupled to an Agilent 7500ce ICPMS system (Mulgrave, Australia). The full methods have been described previously $[38,59]$. Additional iron measurements were performed using liquid phase ICPMS Varian UltraMass 700 (Varian, Australia) [12].

\section{Stereology}

The total number of DA neurons in the SNpc was estimated using a fractionator sampling design [29, 61, 77]. Brains were fixed overnight in $4 \%$ paraformaldehyde in PBS, then cryoprotected in $30 \%$ sucrose until the brains sunk, the SNpc was sectioned in a 1 in 3 series at $30 \mu \mathrm{m}$ with a cryostat (Leica), stained with the $\mathrm{TH}$ antibody, reacted with diamiobenzidine tetrahydrochloride (DAB; Sigma) and counter stained with neutral red [17]. Counts were made at regular predetermined intervals $(\mathrm{x}=140 \mu \mathrm{m}, \mathrm{y}=140 \mu \mathrm{m})$. Systematic samples of the area occupied by the nuclei were made from a random starting point. An unbiased counting frame of known area $(45 \mu \mathrm{m} \times 35 \mu \mathrm{m})$ was superimposed on the image of the tissue sections using stereology software (MBF, Stereo Investigator) utilizing a $63 \times$ objective lens (Leica, N.A.1.36). Experimenters were blinded to the treatments of each of the groups. Every neuron within the SNpc ( $\mathrm{TH}$ - positive and negative) was counted to obtain an estimate of neuronal number. The density of $\mathrm{TH}$ immunopositive varicosities was obtained from the dorsal $400 \mu \mathrm{m}$ of the caudate putamen $(\mathrm{CPu})$ [30].

\section{Cerebrospinal fluid collection from dogs}

The collection of cerebrospinal fluid (CSF) was performed at the conclusion of a 28 day toxicology study in 10 month old Beagle dogs undertaken at Charles River Laboratories Preclinical services Edinburgh UK under appropriate ethics approval. PBT434 was administered by oral gavage once a day for 28 days at the following doses: vehicle control $(0 \mathrm{mg} / \mathrm{kg} /$ day $), 10 \mathrm{mg} / \mathrm{kg} /$ day, $30 \mathrm{mg} / \mathrm{kg} / \mathrm{day}$ and $50 \mathrm{mg} / \mathrm{kg} /$ day. Each treatment arm included 3 male and 3 female dogs. The CSF was extracted at necropsy into collection tubes containing $10 \mathrm{uL}$ of butylated hydroxytoluene, frozen on dry ice and stored at $-80{ }^{\circ} \mathrm{C}$ until analysis. Any samples showing signs of hemolysis were excluded due to the potential for contamination of $\alpha$-synuclein from blood [52].

\section{Cerebrospinal fluid collection from rats}

Cannulas were inserted into the lateral cerebral ventricles of wild-type rats by stereotactic surgery. CSF sampling was performed using a rodent microdialysis bowl (BASi, $n=8$ ). Baseline CSF was sampled after which the animals were gavaged with PBT434 at $30 \mathrm{mg} / \mathrm{kg}$. CSF samples were collected at one and four hours after 
gavage with PBT434. Samples were analysed by Western blot for the presence of $\alpha$-synuclein as described.

\section{Statistical analysis}

SPSS version 17.0 (Windows version), was used for all statistical analyses. Any significant differences in the mean scores were denoted by asterisks throughout the manuscript ( ${ }^{*} p<0.05,{ }^{* *} p<0.01$ and $\left.{ }^{* * *} p<0.001\right)$.

\section{Results}

\section{Affinity of PBT434 for metal ions}

PBT434 was found to have a dissociation constant (Kd) for $\mathrm{Fe}$ (III) and $\mathrm{Cu}$ (II) of $\sim 10^{-10} \mathrm{M}$. The affinities for Fe (II) and $\mathrm{Zn}$ were found to be $\sim 10^{-5} \mathrm{M}$ and $\sim 10^{-7} \mathrm{M}$ respectively (Additional file 1: Data S1). Classical high affinity iron chelators such as deferoxamine $\left(\mathrm{Kd} \approx 10^{-31} \mathrm{M}\right)$ and deferiprone $\left(\mathrm{Kd} \approx 10^{-35} \mathrm{M}\right)$ have been evaluated for their potential therapeutic use in iron overload conditions such as thalassemia and in PD [24, 75]. As PBT434 has greater than 20 orders of magnitude less affinity for iron than these classical chelators, it was thought valuable to evaluate whether the large difference in affinities might be reflected in the ability of the respective compounds to promote the efflux of Fe from biological tissues. Cultured neuronal M17 cells were exposed to a trace quantity of the gamma emitting iron isotope ${ }^{59} \mathrm{Fe}$ and then to each compound over a range of concentrations. At the highest concentration $(20 \mu \mathrm{M})$ PBT434 was shown to have a significant but $\sim 5$ fold lesser ability to promote the flow of Fe out of cultured neuronal M17 cells than $20 \mu \mathrm{M}$ deferiprone (Fig. 1). When administered to normal unlesioned mice, PBT434 at the dose of $30 \mathrm{mg} / \mathrm{kg} /$ day for 21 days had no significant effect on brain iron levels or peripheral indices of iron trafficking and metabolism (Additional file 1: Figure S2).

\section{Inhibition of metal mediated redox activity}

PBT434 was assessed for its ability to inhibit redox activity in an in vitro assay modeling an elevated dissociable pool of metals in the presence of the potent reductant dopamine (DA). Fe in the form of Fe (II)-citrate was incubated with DA in aerated buffer, and $\mathrm{H}_{2} \mathrm{O}_{2}$ production was assessed. PBT434 significantly inhibited $\mathrm{H}_{2} \mathrm{O}_{2}$ production by iron (Fig. 1c). An analog of PBT434 (PBT434-met) was synthesized in which the hydrogen of the phenolic hydroxide substituent was replaced by a methyl group, abolishing its ability to bind metals. The PBT434-met analog was unable to suppress $\mathrm{H}_{2} \mathrm{O}_{2}$ production (Fig. 1c).

\section{Iron mediated aggregation of $a$-synuclein}

In an in vitro assay modeling iron-mediated acceleration of $\alpha$ - synuclein aggregation, PBT434 significantly reduced the rate of $\mathrm{Fe}$-mediated aggregation of $\alpha$-synuclein as measured by the lag-time for the detection of fluorescent aggregates compared with $\alpha$-synuclein/Fe alone. In

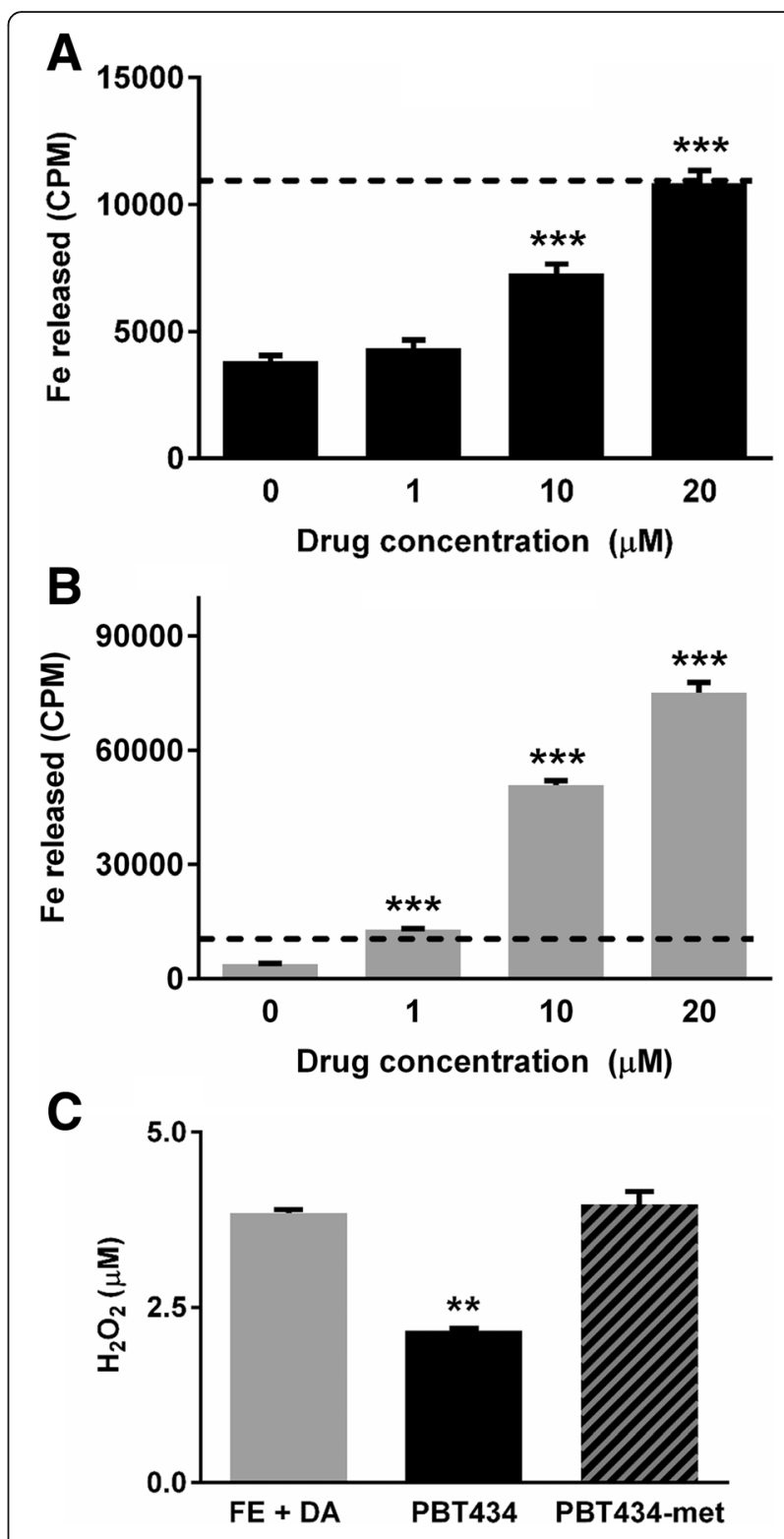

Fig. 1 PBT434 enhances the release of iron and prevents the generation of hydrogen peroxide. Cultured M17 neuroblastoma cells were loaded with the iron isotope ${ }^{59} \mathrm{Fe}$. The cells were washed and then exposed to a chelator to assess if iron could be removed from the cell. Cells loaded with the iron isotope ${ }^{59} \mathrm{Fe}$ were exposed to a PBT434 and the amount of radioactive ${ }^{59} \mathrm{Fe}$ released into the media was measured (CPM = counts per minute) or $\mathbf{b}$ deferiprone at $0,1,10$ or $20 \mu \mathrm{M}$ for $3 \mathrm{~h}$. Deferiprone showed a dose related increase in the levels of ${ }^{59} \mathrm{Fe}$ secreted into growth medium. With PBT434 the effect was observed only at the highest dose of $20 \mu \mathrm{M}$ $\left({ }^{*} P<0.05,{ }^{* *} P<0.01,{ }^{* * *} P<0.0001\right.$, One-way ANOVA, Tukey Post Hoc). At the highest concentration, the effect of deferiprone was 5 -fold greater than for PBT434. The dashed line represents equivalent values on the two graphs. c PBT434 causes an inhibition of metal mediated redox activity. Fe-citrate $(0.4 \mu \mathrm{M})$ in the presence of dopamine (DA, $50 \mathrm{mM}$ ) generate hydrogen peroxide $\left(\mathrm{H}_{2} \mathrm{O}_{2}\right)$ assessed using a cell-free fluorescence-based assay. PBT434 at $10 \mu \mathrm{M}$ but not PBT434-met significantly reduced $\mathrm{H}_{2} \mathrm{O}_{2}$ generated by Fe/DA (PBT434-met = analog of PBT434 in which the metal binding site is blocked; One-way ANOVA, Tukey Post Hoc). Dopamine without Fe-Citrate did not produce $\mathrm{H}_{2} \mathrm{O}_{2}$ 
contrast, PBT434-met did not inhibit the rate of Femediated aggregation (Fig. 2), consistent with the aggregation being caused by Fe coordination.

\section{Neuroprotective effects of PBT434}

Pharmacokinetic (PK) data showed that PBT434 was orally bioavailable, readily penetrated the blood brain barrier, and was well-tolerated in mice (Additional file 1: Data S3). The effect of PBT434 was initially tested in the mouse 6-OHDA toxin model, where oral PBT434 ( $30 \mathrm{mg} / \mathrm{kg} /$ day) was administered 3 days after the toxin (Fig. 3a, b and Additional file 1: Fig. S4). PBT434 prevented neuronal loss following 6-OHDA, preserving up to $75 \%$ of the SNpc neurons remaining (both Nissl and tyrosine hydroxylase (TH) positive neurons) after the initial phase of cell death $(p<0.001)$. While rotational behavior was improved with both L-DOPA $(20 \mathrm{mg} / \mathrm{kg} /$ day $)$ and PBT434, L-DOPA did not prevent nigral damage.

Subsequent studies were only performed using the MPTP intoxication model, which permitted higher throughput and larger animal numbers per trial. The toxin-induced time course of SNpc cell death caused by MPTP is characterized by initial phase of rapid cell death, followed by a more gradual cell loss continuing up to 21 days after the initial insult $[48-51,65,86]$. We confirmed this pattern of cell loss in our MPTP paradigm using stereological counting of SNpc neurons on days $1,3,10$ and 21 following administration of toxin (Additional file 1: Fig. S4). To avoid possible interactions with the toxin, PBT434 was administered to MPTPtreated mice one-day post intoxication. Animals in the treatment arm were gavaged once daily with PBT434 or its nonmetal binding analog PBT434-met, each at $30 \mathrm{mg} / \mathrm{kg} / \mathrm{day}$ (a dose which preliminary studies established was well tolerated, Additional file 1: Data S3). PBT434 was tested in 12 separate experiments. On average across these trials, MPTP induced a $44 \% \pm 4 \%$ depletion of $\mathrm{SNpc}$ neurons. The PBT434-met analog control had no significant effect (Fig. 3c). Motor activity in MPTP treated mice was assessed at 21 days by pole test. We adopted the pole test for the MPTP studies, as this task is sensitive to MPTP-induced denervation $[44,45,61,69]$. When compared with vehicle alone PBT434 significantly reduced MPTP-mediated motor deficits in the pole test $(p<0.001$; Fig. 3d).

\section{Dose-response}

In order to establish if a dose-response relationship existed, we administered 1, 3, 10, 30 or $80 \mathrm{mg} / \mathrm{kg}$ PBT434 to MPTPchallenged mice for 20 days, as described. SNpc neuron number (Fig. 4a) and motor performance (pole test, Fig. 4b) were assessed for each dose arm at day 21 post-intoxication. The proportion of SNpc cells preserved increased incrementally with increasing dose of PBT434 with significance becoming apparent at $3 \mathrm{mg} / \mathrm{kg} /$ day, and maintained at 10, 30 and $80 \mathrm{mg} / \mathrm{kg} /$ day. As the dose of PBT434 increased there was a dose-dependent improvement motor performance on
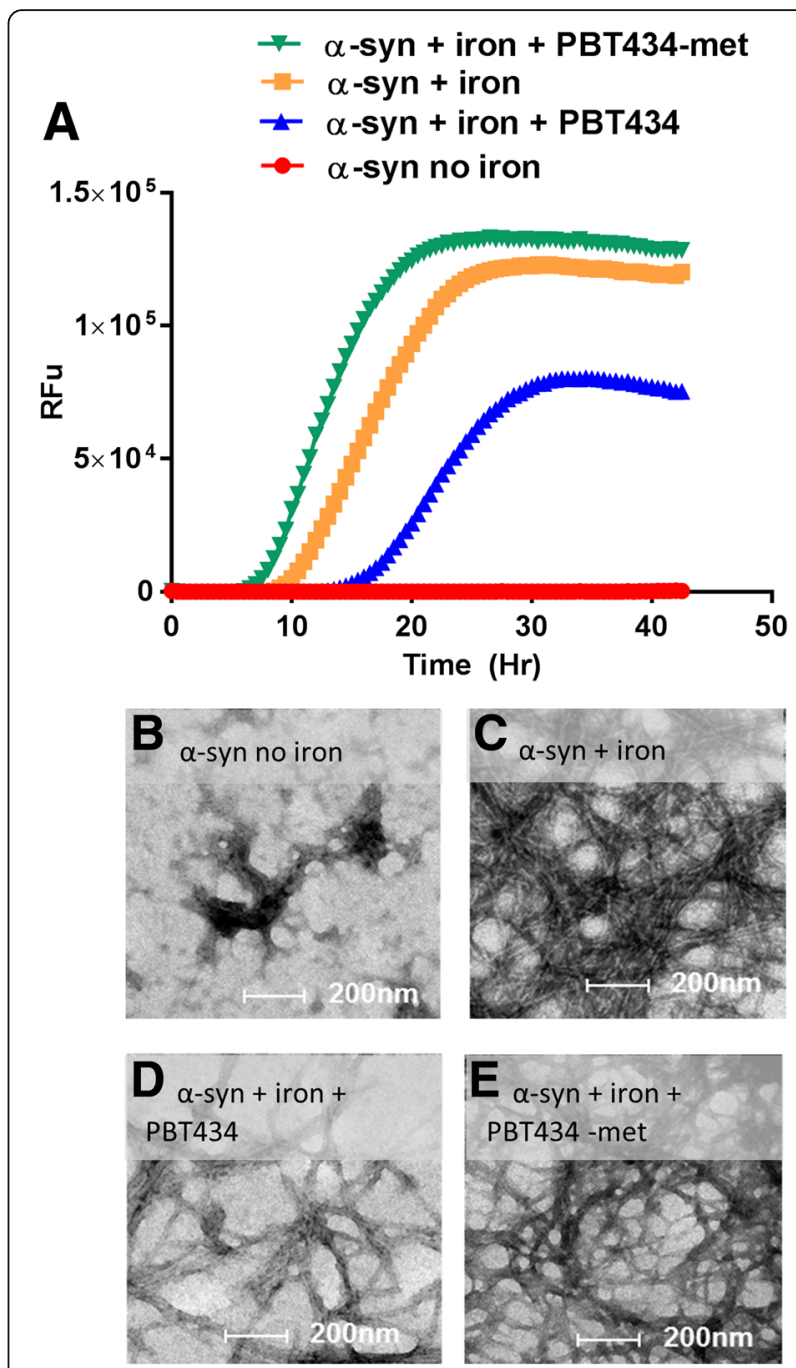

Fig. 2 Inhibition of iron mediated a-synuclein (a-syn) aggregation. Recombinant a-synuclein $(186.6 \mu \mathrm{M})$ was incubated alone or in the presence of equimolar concentrations of iron nitrate (iron $=\mathrm{Fe}\left(\mathrm{NO}_{3}\right)_{3}$ ), PBT434 or PBT434-met. Thioflavin T (ThT) fluorescence was measured (RFU = relative fluorescent units) every $30 \mathrm{~min}$ for $42 \mathrm{~h}$. The lag-time of aggregation was slowed by PBT434 (a-synuclein $=37 \mathrm{~h}$, $\mathrm{a}-$ syn + iron $=10.2 \mathrm{~h}$, a-syn + iron + PBT434 $=16.60 \mathrm{~h}$ and a-syn + iron + PBT434-met =7.9 h). a One Way ANOVA with games-howell post hoc analysis (unequal variances on the lag-phases, individual reaction wells $(n=5-6)$ showed that, $\mathrm{a}-\mathrm{syn}+$ iron had significantly faster aggregation than a-syn + iron + PBT434 ( $p=0.02)$ or a-syn alone $(p=0.04)$ but not $a-$ syn + iron + PBT434-met $(p=0.49)$. Lower panels: Electron micrographs of samples from each reaction mixture were taken after $42 \mathrm{~h}$ (b; a- synuclein, no iron); c Increased fibril formation in the presence of iron; $\mathbf{d}$ Diminished fibril formation in the presence of PBT434; E) PBT434-met did not reduce the fibril formation

the pole test, reaching significance at $30 \mathrm{mg} / \mathrm{kg} / \mathrm{day}$, and almost completely rescued at $80 \mathrm{mg} / \mathrm{kg} /$ day.

\section{Nigro-striatal connectivity}

Varicosities are the sites where the axons of SNpc neurons synapse with neurons in the caudate/putamen. Typically, 

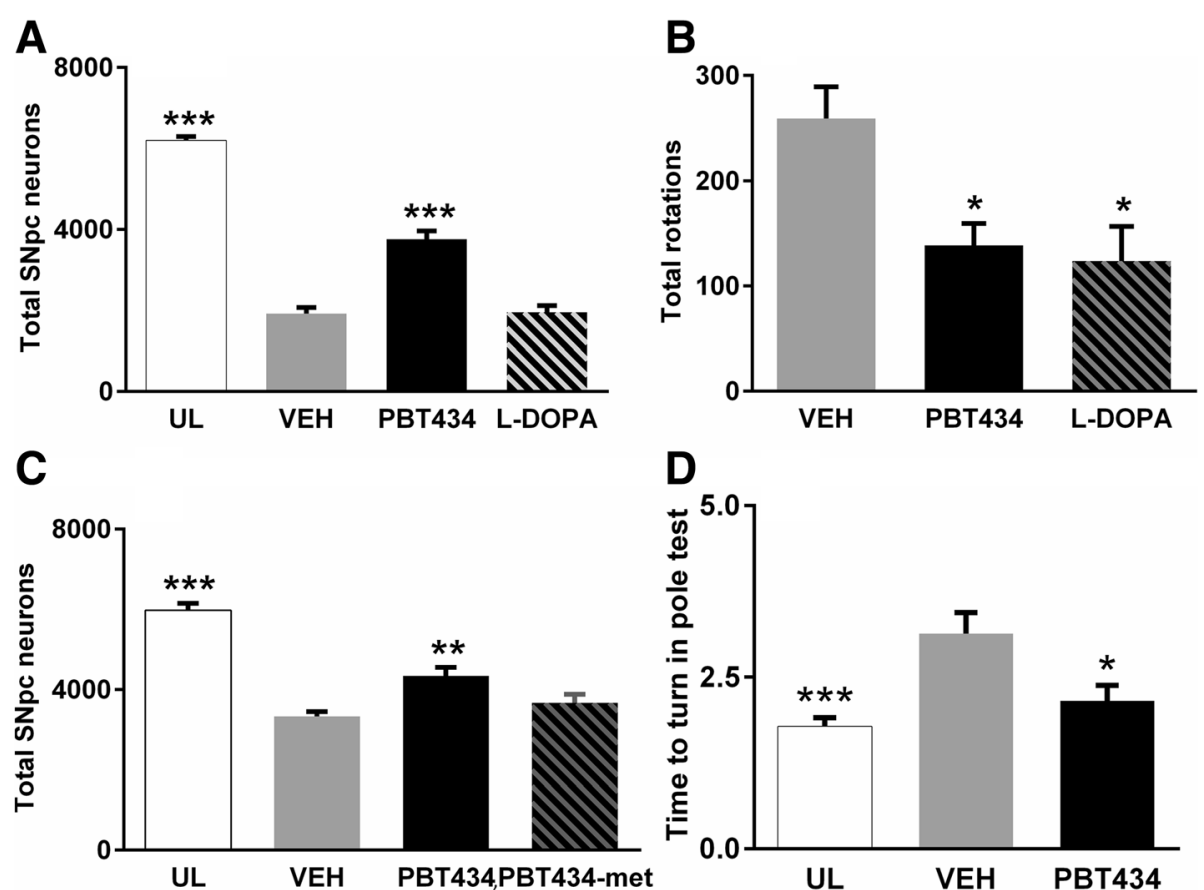

Fig. 3 PBT434 prevents toxin induced cell loss and improves motor performance. a 6-OHDA injection resulted in the loss of 65\% of the SNpc neurons compared with unlesioned control animals. PBT434 administration commencing 3 days following intoxication and significantly preserved neuron numbers compared with vehicle ( $p<0.001$, One-way ANOVA, Tukey Post Hoc). The number of neurons in an unlesioned mouse is $6124 \pm 23$. L-DOPA did not protect neurons against 6-OHDA toxicity. $\mathbf{b}$ Mice treated with PBT434 (30 mg/kg/day, $N=11(P<0.05)$ or L-DOPA (15 mg/kg, $P<0.001$, One-way ANOVA, Tukey Post Hoc) showed significantly fewer rotations than vehicle treated mice. c PBT434 (30 mg/kg/day for twenty days) administered $24 \mathrm{~h}$ following intoxication with MPTP resulted in significantly reduced SNpc neuronal loss (*** $P<0.001$, One-way ANOVA, Tukey Post Hoc). PBT434-met 30 mg/kg/day (PBT434 without the metal binding site) does not protect against MPTP. d PBT434 treatment resulted in improvement in motor performance in the Pole test ( ${ }^{*} P<0.05$, One-way ANOVA, Tukey Post Hoc). UL $=$ unlesioned, VEH $=$ standard suspension vehicle without compound, PBT434-met $=$ analogue of PBT434 without the metal binding

in PD and in MPTP lesions there is substantial loss of these synapses. At 21 days after MPTP intoxication, THpositive varicosities in vehicle treated animals were reduced by more than $50 \%$ compared with unlesioned mice $(p<0.05)$. The number of TH- positive varicosities was significantly higher in PBT434-treated animals at both 30 and $80 \mathrm{mg} / \mathrm{kg}$ when compared with untreated animals (Fig. 4c, d). In a complementary study, we found that MPTP treatment significantly reduced levels of the presynaptic protein synaptophysin, and this lesion was abolished by treatment with PBT434 (30 mg/kg/day) (Fig. 4e).

\section{Effects of PBT434 upon toxin-mediated elevation of iron}

We applied laser ablation inductively-coupled plasma mass spectrometry (LAICPMS) $[38,39,58]$ to monitor the level and distribution of iron in the SN of test animals. This technique, while providing more information than manual microdissection, could not discriminate between SN pars reticulata and SNpc. Not to our knowledge reported previously, MPTP challenge caused iron levels to rise in several brain regions 21 days after the MPTP. Iron levels in the SN were elevated by around $25 \%$ compared with the control animals at day 21, and were normalized by PBT434 treatment (30 $\mathrm{mg} / \mathrm{kg} /$ day by oral gavage) (Fig. 5a). Solution phase ICPMS applied to SNpc tissue dissected manually from a separate MPTP/ PBT434 cohort confirmed these results, and found that neither MPTP nor PBT434 significantly affected SNpc copper levels (Additional file 1: Figure S5).

\section{Oxidative stress markers}

In MPTP lesioned animals, levels of the oxidative stress marker 8-isoprostane in the $\mathrm{SNpc}$ were elevated to over $200 \%$ those of the unlesioned controls. 8-isoprostane levels in the corresponding PBT434-treated cohort did not rise significantly above control levels (Fig. $5 \mathrm{c}$ ). Conversely, DJ-1 levels were significantly increased by MPTP and further elevated in PBT434-treated animals (Fig. 5d).

\section{Effect of PBT434 upon MPTP-mediated elevation of a -synuclein}

MPTP intoxication in wild-type mice has been reported to cause an increase in $\alpha$-synuclein protein levels in the SNpc $[79,89]$. We found that MPTP induced a 


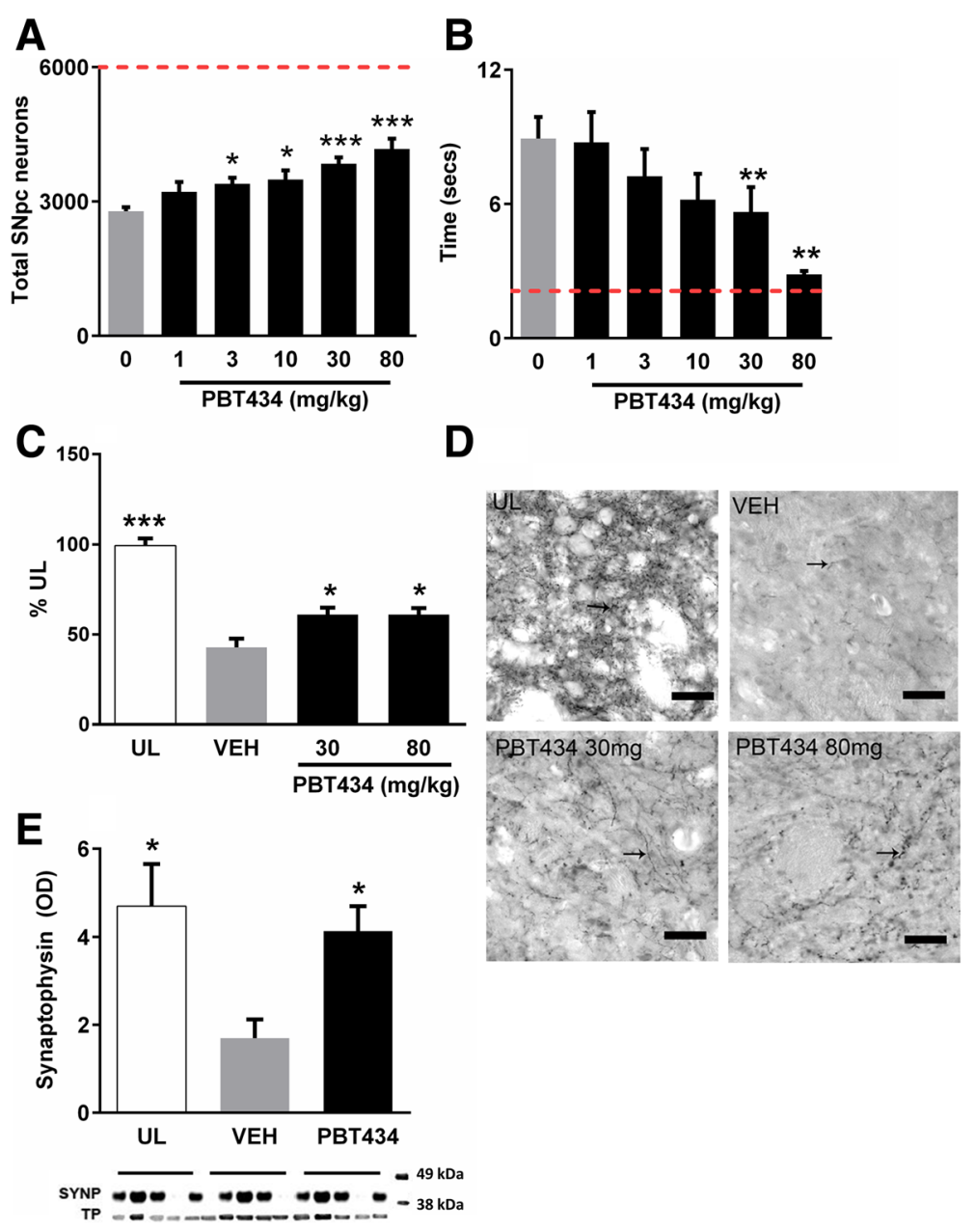

Fig. 4 Dose response effects of PBT434 on neuron number and TH - positive varicosities. The effects on SNpc neuron number and motor function in response to escalating dose of PBT434 were assessed. 12-14 week old male C57BL/6 mice were lesioned using MPTP (60 mg/kg) resulting in an average SNpc lesion size of 55\%. Treatment with PBT434 at 1,3,10, 30 or $80 \mathrm{mg} / \mathrm{kg} /$ day commenced $24 \mathrm{~h}$ after induction of lesion. a Mean number of SNpc neurons compared with the vehicle treated group $(V E H)( \pm S E M)$. The proportion of SNpc cells rescued increased with increasing dose of PBT434. $3 \mathrm{mg}(P<0.05), 10 \mathrm{mg}(P<0.01), 30 \mathrm{mg}(P<0.001)$ and $80 \mathrm{mg} / \mathrm{kg} /$ day $(P<0.001)$ doses prevented a significant proportion of cell loss by day 21 (73 animals were studied from two separate MPTP experiments; One-way ANOVA paired with Games-Howell post hoc test). The red dotted line indicates the normal value. b Pole test was undertaken at day 20 post intoxication to test motor performance. As the dose of PBT434 increased there was a trend to improved turning behavior compared with the vehicle group while doses $30 \mathrm{mg} / \mathrm{kg} / \mathrm{day}$ $(P<0.05)$ and $80 \mathrm{mg} / \mathrm{kg} / \mathrm{day}(P<0.01)$ showed a significant $2.5-3$ fold improvement in the time to turn. (One-way ANOVA paired with GamesHowell post hoc test). The dashed line represents the average time taken by unlesioned animals to perform the task. $\mathbf{c}$ The abundance of tyrosine hydroxylase-positive varicosities in the caudate putamen was assessed by stereology at day 21 following MPTP ( $N=6-7$ animals per treatment). Following MPTP intoxication, TH -positive varicosities were reduced compared with unlesioned mice $\left(^{*} p<0.05\right.$. One-way ANOVA, Tukey's Post hoc comparison). Treatment with 30 or $80 \mathrm{mg} / \mathrm{kg}$ of PBT434 significantly increased varicosity abundance compared with untreated mice. $\mathbf{d}$ Light micrographs of the dorso-lateral tier of the caudate putamen showing individual tyrosine hydroxylase -positive varicosities (arrows), for unlesioned animals (UL), MPTP lesioned vehicle treated (VEH) or following PBT434 treatment (scale bar $=25 \mu \mathrm{m}$ ). e Western blots of the dorsal tier of the caudate putamen showed that treatment with PBT434 prevented the decline in levels of the presynaptic marker synaptophysin (SYNP), ${ }^{*} p<0.05$, One-way ANOVA, Tukey Post hoc comparison). TP = total protein, OD = optical density

significant and marked rise in $\alpha$-synuclein levels in the SNpc that persisted at day 21, and was abolished by concurrent PBT434 treatment (Fig. 5e).

\section{Effect on ferroportin}

In previous work we showed that iron accumulation in an animal model of Parkinsonism was associated with failure of the iron export apparatus $[4,5,61]$. Consistent with previous reports [26], we found that MPTP caused a profound reduction in levels of the iron export protein ferroportin in the SNpc. Treatment with PBT434 (30 $\mathrm{mg} / \mathrm{kg} /$ day for 20 days), prevented this and ferroportin protein levels remained similar to those of unlesioned animals (Fig. 5f). 

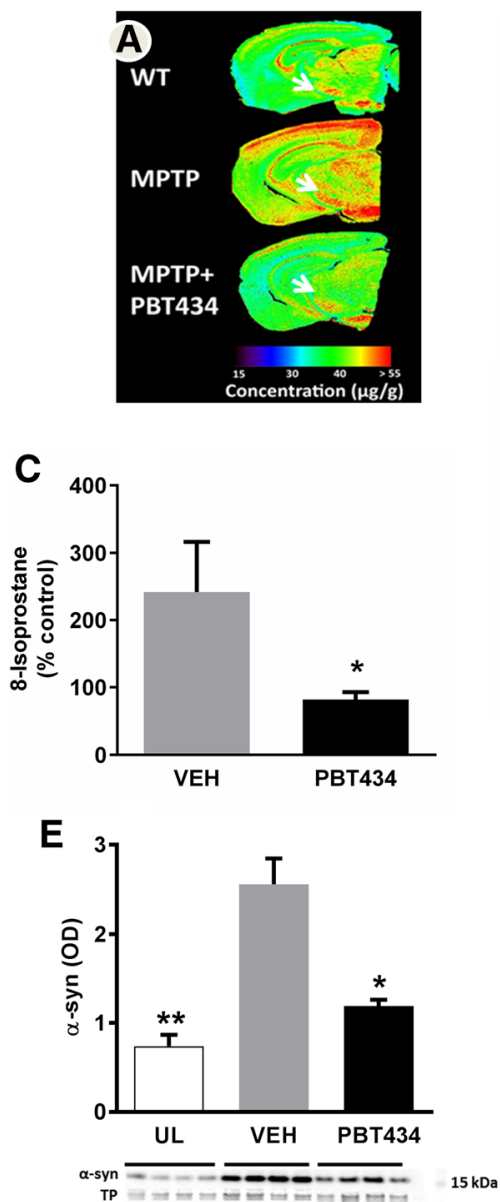
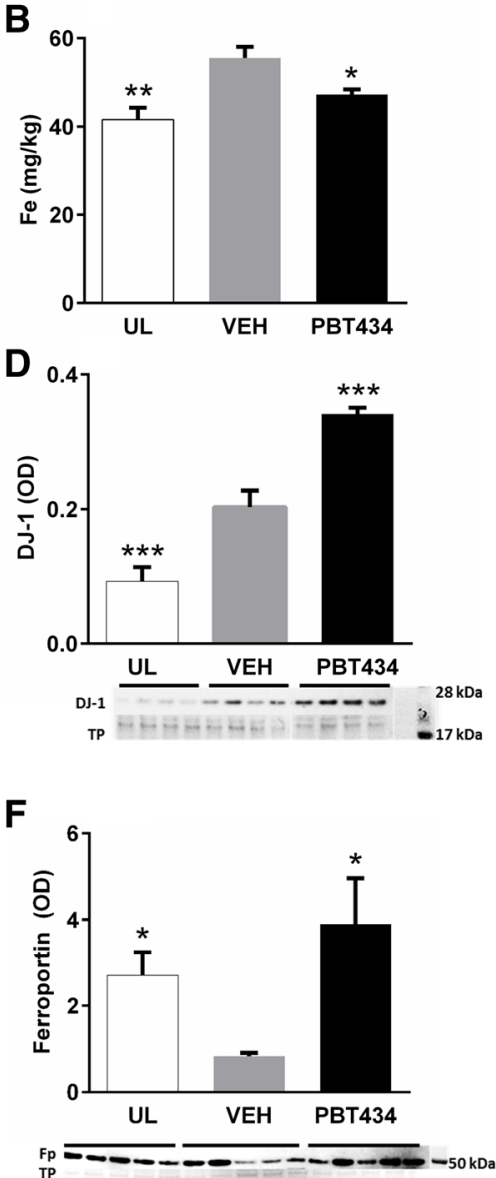

Fig. 5 PBT434 improves iron level following MPTP lesion. 12-14 week old male C57BL/6 mice were lesioned using MPTP which resulted in a lesion size $65-70 \%$ cell loss by day 21. MPTP lesioned mice were treated with vehicle (VEH) or PBT434 (30 mg/kg/day) from day 1 to day 21 . a Brain samples collected at day 21 were sectioned and scanned using laser ablation-inductively coupled plasma-mass spectrometry. Representative images show Fe distribution in normal, unlesioned, wildtype (C57BL6) mouse brain, MPTP lesioned brain and MPTP + PBT434 treated brain. The heat map quantifies the level of iron in the SN, which is indicated by the arrow. b The concentrations of Fe $(\mathrm{mg} / \mathrm{kg})$ in the substantia nigra $(\mathrm{SN}$, includes both compacta and reticulata) of the groups of mice were plotted onto a bar graph. MPTP injury causes a significant elevation in Fe in the SN at day $21\left({ }^{* *} p<0.01\right.$, one-way ANOVA, Tukey post hoc) compared with unlesioned mice (UL) which was attenuated by PBT434 $\left({ }^{*} p<0.05\right.$, one-way ANOVA, Tukey post hoc). c PBT434 significantly prevented the MPTP induced elevation of 8-isoprostane within SN as measured by ELISA $\left({ }^{*} P<0.05\right.$, One-way ANOVA, Tukey Post Hoc). $\mathbf{d}$ Western blot was used to measure levels of levels of DJ-1 in the SN. Levels of DJ-1 were significantly elevated with MPTP treatment in the absence of drug (VEH) and significantly further elevated with PBT434 (TP = Total Protein; OD = optical density; *** $<0.001$, One-way ANOVA, Tukey post hoc). The protein ran at the predicted molecular weight ( $24 \mathrm{kDa})$ as can be seen by comparing the position of the proteins with the molecular weight ladder on the right of the image. e a-synuclein levels in mice administered MPTP or MPTP + PBT434 (30 mg/kg/day, were compared with unlesioned controls; UL). SN tissue samples were homogenized to form a lysate, which was assayed by Western blot and quantitated by optical density (OD) normalized to total protein (TP, Ponceau). The protein ran at the predicted molecular weight $14 \mathrm{kDa}$ compared to with the molecular weight ladder on the right of the image. In MPTP lesioned mice a-synuclein was significantly elevated by day 21 $\left({ }^{* *} P<001\right.$, one-way ANOVA, Tukey post hoc). a-synuclein protein levels were significantly lower with PBT434 treatment ( $* P<0.05$, one-way ANOVA, Tukey post hoc) compared with Vehicle treated animals. $\mathbf{f}$ Western blot of MPTP lesioned mice showed a significant reduction in levels of ferroportin protein which were decreased 21 days after the lesion $\left({ }^{*} P<0.05\right)$. The protein ran at slightly less the predicted molecular weight $63 \mathrm{kDa}$ compared to with the molecular weight ladder on the right of the image. Ferroportin protein levels were significantly higher with PBT434 treatment $(* P<0.05)$ compared with the vehicle treated animals but not different to unlesioned mice (one-way ANOVA, Tukey post hoc)

\section{Effect of PBT434 in the a-synuclein transgenic (hA53T) mouse}

We tested whether the neuroprotective effects of PT434 could be reproduced in a genetic model of PD. The hA53T mutant $\alpha$ - synuclein transgenic mouse has a subtle disease phenotype $[12,14,31,35$,
72]. At 8 months of age, the hA53T mice exhibit decreased locomotion in the open field test compared with wild type animals, and hindlimb clasping behavior (Additional file 1: Figure S6), indicative of striatal damage. This is accompanied by a modest but significant decrease in the number of nigral neurons 
between 4 and 8 months of age. Long term (4 months) treatment with PBT434 incorporated into the animal feed (to achieve an average dose of $30-37 \mathrm{mg} / \mathrm{kg} /$ day) from 4 months of age significantly preserved $\mathrm{SNpc}$ neuron number (Fig. 6a) accompanied by increased total movements in the open field test and reduced clasping behavior (Additional file 1: Figure S6). In the Tg mice at 8 months, four months of PBT434 treatment reduced SN iron levels by 15\% (Fig. 6b) PBT434 treatment did not alter the levels of soluble $\alpha$ - synuclein (Fig. 6c). but significantly decreased the nigral insoluble (urea extracted) $\alpha$ - synuclein (Fig. 6d). and significantly increased nigral ferroportin levels (Fig. 6e).

\section{Cerebral spinal fluid (CSF) biomarkers}

In a small exploratory study, CSF collected post-mortem from dogs undergoing a 28 day dose-tolerability study of PBT434 was assayed for soluble $\alpha$-synuclein a dose dependent trend (non-significant) in the reduction of $\alpha$ synuclein was observed (Fig. 7a). To further investigate this phenomenon in a more controlled environment, cannula were surgically implanted into the lateral ventricles of rats $(n=10)$. CSF was sampled before and after gavage with $30 \mathrm{mg} / \mathrm{kg}$ PBT434 and analyzed by Western blot for the presence of $\alpha$-synuclein. At four hours but not at one hour, $\alpha$-synuclein levels were significantly lower than baseline ( $p=0.05$, Fig. 7b).
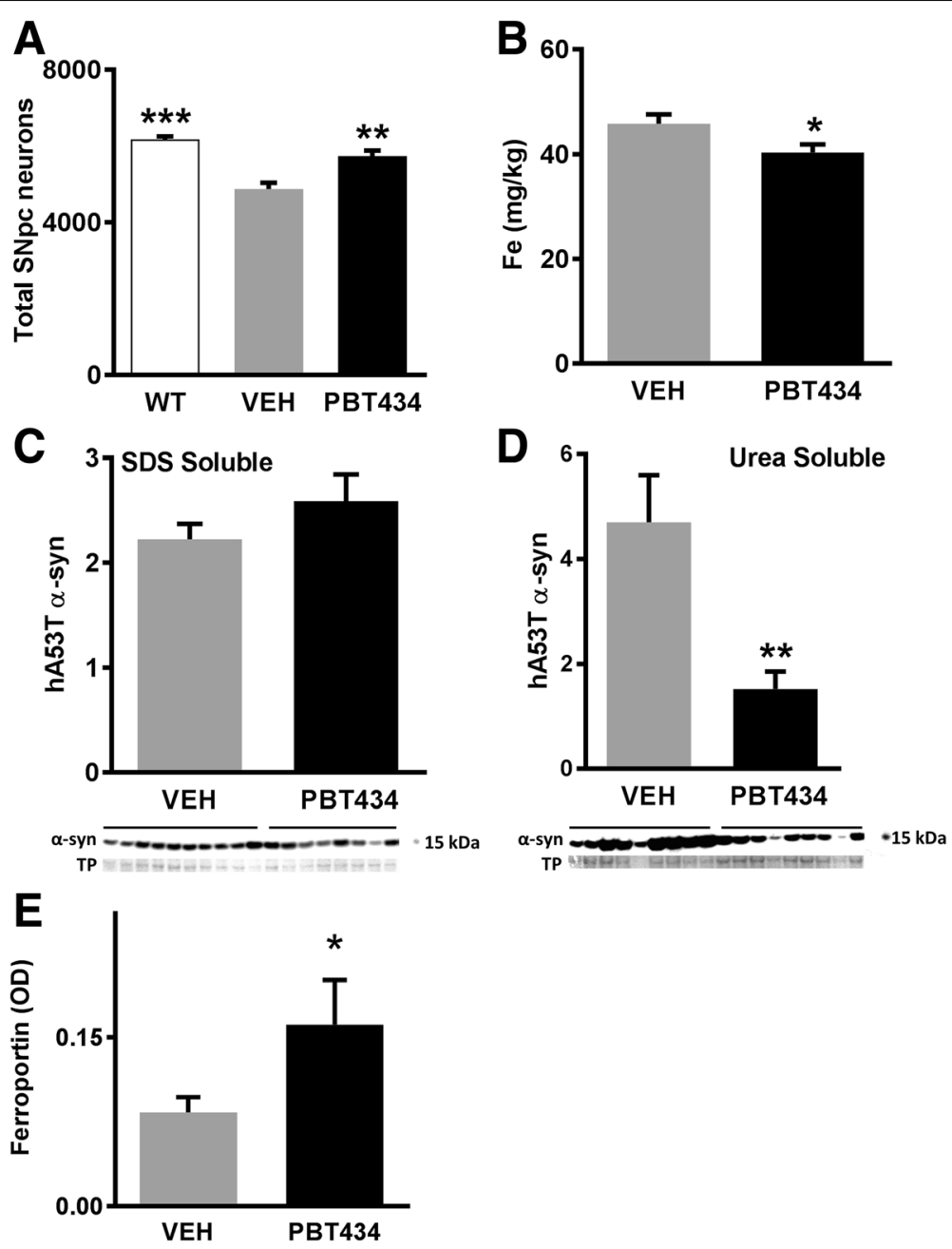

Fig. 6 PBT434 modulates a-synuclein transgenic animals. hA53T a-synuclein Tg mice consumed an average of $37 \mathrm{mg} / \mathrm{kg} / \mathrm{day}$ in animal chow of PBT434 from 4 months of age for 4 months. a PBT434 preserved SNpc neurons (** $P<0.01$, one-way ANOVA, Tukey post hoc); b PBT434 decreased SN iron measured by mass spectrometry ( ${ }^{*} P<0.05$, T-Test). SN tissue samples were homogenized to form a lysate, which was assayed by western blot and quantitated by optical density (OD) normalized to total protein (TP, Ponceau). c PBT434 did not reduced levels of the SDS soluble fraction of a- synuclein in the SN (Western blot, urea soluble fraction); $\mathbf{d}$ PBT434 reduced levels of the urea soluble fraction of a- synuclein in the SN (** $p<0.01$; T-Test); E) PBT434 treatment increased SN ferroportin levels $(* P<0.05$, T-Test) 


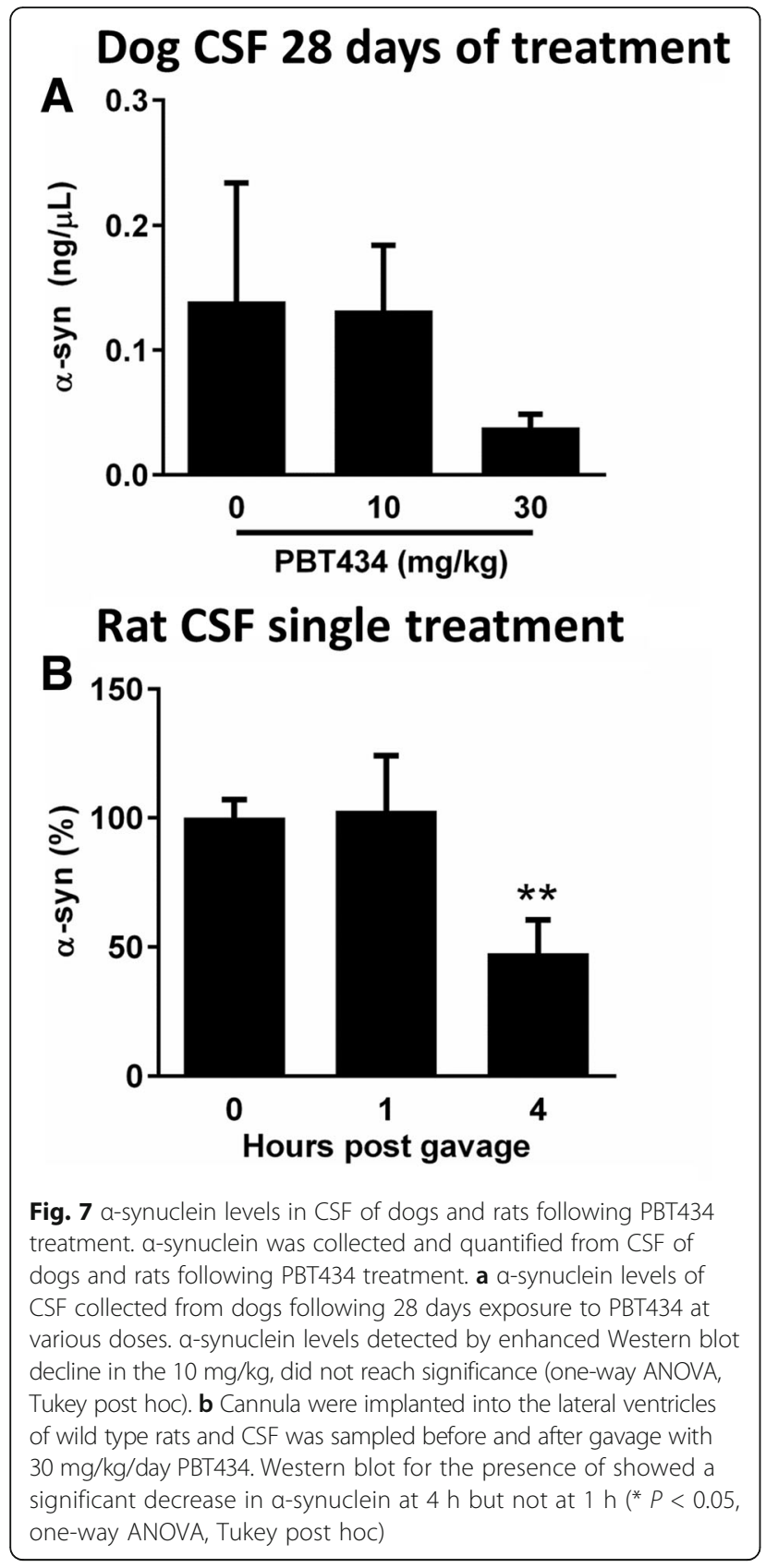

\section{Discussion}

PBT434 is a novel, orally bioavailable, moderate iron affinity 8-hydroxyquinazolinone which is being developed for treatment of Parkinsonian conditions. We adapted commonly used Parkinsonian toxin models and the hA53T $\alpha$-synuclein transgenic mouse to investigate the therapeutic potential of PBT434 to slow or prevent progressive neurodegeneration in PD. We found that PBT434 preserved $\mathrm{SNpc}$ neuron number in animal models of SNpc degeneration and synucleinopathy which translated to improved motor function accompanied by reduced levels of $\alpha$ - synuclein and a reduction in markers of oxidative stress. The observation that the analog of PBT434, (PBT434-met), in which the metal binding site was blocked, had no protective effect, is consistent with the proposed metal-centric mechanism of action.

Although there is an accumulation of iron in the neurons of the $\mathrm{SN}$ in $\mathrm{PD}$ [71], it may be simplistic to characterize the condition as a disease of iron overload analogous to hemochromatosis or thalassemia in which potent chelators are required for clinical effect [75]. Evidence suggests rather, that subtle alterations to mechanisms maintaining metal homeostasis are disrupted, leading to anatomically localized deficits and surpluses [4-6, 61]. Inevitably this results in an increase in the weakly bound or labile metal pool $[7,8]$, including iron, a potent generator of free-radicals. Recent findings have placed iron close to the center of pathological events $[5,21]$. For instance, it has been recently demonstrated that cellular reactive oxygen species production by $\alpha$ synuclein oligomers is entirely dependent on the presence of free metal ions, as addition of metal chelators could block oligomer-induced reactive oxygen species production and prevent oligomer-induced neuronal death [23]. Furthermore, oxidative stress, a feature of both disease and aging is now understood to be sufficient in of itself to engender the deterioration in the performance of the iron trafficking apparatus which is manifested in aberrant iron distribution $[21,68,76]$.

With a Kd around $10^{10}$ the affinity of PBT434 for iron is considered moderate compared with physiological iron ligands such as transferrin ( $\mathrm{Kd} 10^{23}$ ) [3] and orders of magnitude lower than iron chelators in clinical use such as deferiprone $\mathrm{Kd} 10^{35}$ ) [55]. The significantly lesser efflux of iron from cultured cells engendered by PBT434 compared with deferiprone reflects the widely differing $\mathrm{Kds}$ and physicochemical properties of the two drugs. As a corollary, no significant effect on global brain iron levels in normal intact mice was observed within the effective dose range of PBT434.

We assessed the efficacy of PBT434, administered as a single daily oral dose, in attenuating the neurotoxic cascade following intoxication with the Parkinsonian toxins 6-OHDA and MPTP. As SNpc neurons continue to die for weeks after intoxication with both 6-OHDA and MPTP efficacy $[48,50,51,65,86]$, we elected to evaluate the extent of preservation of SNpc neurons at 21 days as the primary measure of efficacy. MPTP has the advantage of being able to produce larger numbers of uniformly lesioned animals, therefore most the studies were undertaken using the MPTP model. By delaying administration of PBT434 until the toxin is known to have been cleared $[47,90]$ we obviated the possibility of false positive results caused by incidentally neutralizing the toxin, by blocking its uptake, or by preventing its 
conversion to MPP+ [56]. The 6-OHDA toxin has similar potential for interactions with test compounds, therefore PBT434 administration was delayed until $72 \mathrm{~h}$ after intra-nigral injection of 6-OHDA. 6-OHDA lesion size being directly related to the rotational behavior (Additional file 1: Figure S4). Further stringency was introduced by selecting only those mice that rotated 200450 times an hour. The presence of an MPTP-induced lesion is related to motor dysfunction although unlike 6OHDA, no direct correlation has been shown between lesion size and motor performance [45, 69]. We found the MPTP-affected brain to be sensitive to dose of PBT434; incremental improvements in SNpc neuron viability reflected in similarly dose-dependent improvements in motor function (Fig. 4). While increasing survival of SNpc neurons is important, in order for function to be maintained, connectivity between these neurons and their synaptic partners in the striatum is required. PBT434 preserved nigro-striatal synaptic circuitry, reflected in the abundance of terminal varicosities. The maintenance of nigro-striatal synaptophysin protein at levels seen in intact animals supports the conclusion that preservation of connectivity is likely a major contributor to the improvement in motor function observed with PBT434.

As ferroportin is the primary iron exporting protein, the precipitous drop in ferroportin levels following the MPTP insult may be sufficient to explain the rise in SNpc iron [60]. Presumably, the effect of PBT434 in sustaining ferroportin levels is a beneficial consequence of its neuroprotective effect although a direct effect cannot yet be ruled out.

It has been reported that iron, copper and dopamine under oxidizing conditions each foster the aggregation of $\alpha$-synuclein and the formation of toxic soluble oligomeric species $[19,43,63]$. The sharp rise in $\alpha$-synuclein levels following MPTP treatment is well documented [89]. We speculate that in the MPTP model PBT434 modulates $\alpha$-synuclein expression via the iron responsive element on the $5^{\prime}$ untranslated region of its mRNA by sequestering weakly bound cellular iron. It has been reported that $\alpha$-synuclein itself has ferri-reductase activity capable of reducing Fe III to Fe II which lends further weight to the argument that its expression is likely finely tuned to the presence of iron [22]. The reduction in $\alpha-$ synuclein in the A53T mouse cannot be explained by altered expression, as the A53T transgene does not encode the IRE sequence which would permit it to respond to alterations in cellular iron levels. As noted previously, over the course of treatment the level of nigral iron in the transgenic mice did decline by a modest but significant $15 \%$. We hypothesize that this reflects an enlarged pool of labile or weakly bound iron previously identified as a feature of the Parkinsonian brain [54], which may interact aberrantly with $\alpha$-synuclein to promote aggregation and deposition.

We postulated that if the ability of PBT434 to prevent the elevation in $\alpha$-synuclein levels following MPTP in wild type mice was due to its effect on the labile iron pool, that same effect might also be detectable in healthy animals. Examination of samples of post-mortem CSF from healthy dogs treated with PBT434 for 28 days showed a significant dose-dependent reduction in $\alpha$ synuclein, an effect also observed in rats fitted with an indwelling ventricular catheter, consistent with the hypothesis that PBT434 modulates $\alpha$-synuclein expression at the translational level. This finding raises the possibility that CSF $\alpha$-synuclein may be of value as a marker of target engagement in the clinical setting. There is considerable debate and some justifiable skepticism surrounding the use of biomarkers like CSF $\alpha$-synuclein as indices of disease progression [52], however, such biomarkers, especially if they are demonstrably linked to drug mechanism of action, may be judiciously applied to the evaluation of target engagement for new drugs, assisting in the early phases of clinical development.

The potential for oxidative damage is increased when the normally tight control over the trafficking of redox active metals is impaired. Such impairment may be related to altered activity of the metal trafficking apparatus $[8,80]$ or more indirectly through impaired function of iron dependent enzymes of the (mitochondrial) oxidative phosphorylation apparatus and enzymes such as hypoxia inducible factor (HIF) which have roles in the adaptation to hypoxic or oxidative stress [84]. The marked reduction in 8-isoprostane levels observed in the MPTP treated mice following treatment with PBT434 indicates that its anti-oxidant properties translate to the in vivo milieu.

Defects in the gene encoding the protein deglycase DJ-1 are a cause of autosomal recessive early-onset Parkinson's disease [37]. In pro-oxidative conditions, DJ-1, also known as Park7, has been shown to inhibit the aggregation of $\alpha$-synuclein, to function as a redoxsensitive chaperone [83], as a sensor for oxidative stress and as a mitochondrial pacemaker minimizing oxidative stress associated with dopamine secretion [37]. It has also been shown to bind metals and protect against metal mediated toxicity [13]. The effect of PBT434 upon this multifaceted protein is particularly intriguing because intoxication with MPTP causes a substantial rise in DJ-1 which is further enhanced by treatment with PBT434. Further investigation will reveal the role of DJ-1 in the response to MPTP and where that pathway intersects with the mechanism of action of PBT434. In vitro, DJ-1 has been shown to inhibit the toxicity of A53T $\alpha$-synuclein [91, 92]. In our hands, by the age of 8 months, there was as yet scant 
evidence of acute oxidative damage in the A53T mice similar to the MPTP model, nor did we observe alterations to the levels of DJ-1. Literature sources suggest that any such damage may be more subtle, manifested in oxidation of mitochondrial proteins [66] and in particular in post translational modifications of $\alpha$-synuclein itself such as oxidation or nitration [88].

\section{Conclusions}

Genetic and experimental evidence strongly implicate $\alpha-$ synuclein in the etiology of Parkinson's disease, recommending this protein as a plausible target for potential disease modifying therapies. As understanding of the role of iron in the pathological process in PD evolves, evidence is emerging that $\alpha$-synuclein levels may be modulated by selective targeting of this ubiquitous biometal. PBT434 was developed to exploit this therapeutic niche and in addition to its potential utility in the clinic will be a valuable tool for studying the role of metals in modulating $\alpha$-synuclein levels, the role of oxidative stress as an initiator and perpetuator of the nigral lesion and the involvement of other components of the neuronal iron trafficking apparatus. Treatments currently available for PD and the atypical Parkinsonian conditions at best provide limited symptomatic relief and do not alter disease progression. The beneficial effects of PBT434 on motor function, neuropathology and biochemical markers of disease state in three different animal models of PD suggest disease modifying potential.

\section{Additional file}

Additional file 1: Data S1. Potentiometric determination of PBT434 affinity for $\mathrm{Fe}(\mathrm{III}), \mathrm{Fe}(\mathrm{II}) \mathrm{Cu}(\mathrm{II})$ and $\mathrm{Zn}(\mathrm{II})$ lons. Figure S2. Effect of PBT434 on brain iron and peripheral markers of iron metabolism. Data S3. Pharmacokinetics, pharmacodynamics and safety. Figure S4. Experimental schema. Figure S5. Fe and Cu levels in SNpc (solution ICP-MS). Figure S6. Effect of PBT434 on the phenotype of the transgenic hA53T. (DOCX $4044 \mathrm{~kb})$

\section{Abbreviations}

6-OHDA: 6-hydroxydopamine; CPM: Counts per minute; CPu: Caudate putamen; CSF: Cerebral spinal fluid; DA: dopamine; Kd: dissociation constant; L-DOPA: L-3,4-dihydroxyphenylalanine; MPTP: 1-methyl-4-phenyl-1,2,3,6tetrahydropyridine; PBT434: 8-hydroxyquinazolin-4(3H)-one; PBT434-met: PBT434 in which the metal binding site was blocked; PD: Parkinson's disease; PK: Pharmacokinetic; RFU: Relative fluorescent units; SNpc: substantia nigra pars compacta; TH: tyrosine hydroxylase; TP: total protein

\section{Acknowledgements}

This work is the culmination of many years of dedicated efforts and talents of: Irene Volitakis, Lisa Bray, Nichole Critch, Lydia Gunawan, Liu X-M, Krutika L White, Mun-Joo Chuei and Kali Perrones.

\section{Funding}

The work was supported by funds from the National Health and Medical Research Council, The Australian Research Council, The Michael J. Fox Foundation for Parkinson's Disease Research, Parkinsons UK and Prana Biotechnology Ltd. The Florey Institute of Neuroscience and Mental Health acknowledge the strong support from the Victorian Government and in particular the funding from the Operational Infrastructure Support Grant.

\section{Author contributions}

DIF; writing, conceptualization, designed and performed experiments: JLB; data analysis, designed and performed experiments: PAA; writing, conceptualization, review and editing: SA; performed experiments: AS; performed experiments; CLM, writing, conceptualization: SW; performed experiments: DMS; performed experiments: SAC; performed experiments: $W B$, conceptualization performed experiments: IAZ; performed experiments: EK; performed experiments: ALG; performed experiments, review and editing: SM; performed experiments: AIB; conceptualization, review and editing: DJH; performed experiments, development of methodology: PAD, development of methodology; SC; performed experiments: EG, novel chemistry; JP; novel chemistry: PH, novel chemistry: KJB; writing, conceptualization: RAC, writing, conceptualization, designed experiments, Project administration. All authors read and approved the manuscript.

\section{Competing interests}

RAC, KJB, PAA and DIF are paid consultants to and shareholders in Prana Biotechnology Ltd. AIB is a shareholder in Prana Biotechnology Ltd., Mesoblast Pty Ltd., Cogstate Pty Ltd., NextVet Ltd., Collaborative Medicinal Development Pty Ltd., and a payed consultant for Collaborative Medicinal Development Pty Ltd.

\section{Ethics approval}

All procedures involving mice conformed to the Australian National Health and Medical Research Council Code of Practice for the care and use of animals for scientific purposes and were approved by the Florey Institute animal ethics committee (\# 14-012; A total of 1350 C57bl6 mice and 133 transgenic mice (hA53T a-synuclein) were used in this project). All experiments were designed to minimize the number of animals used, pain and discomfort, whilst still providing sufficiently powered group sizes to observe effects.

\section{Author details}

${ }^{1}$ The Florey Institute of Neuroscience and Mental Health, The University of Melbourne, Melbourne, VIC 3010, Australia. ${ }^{2}$ Prana Biotechnology Ltd, Parkville, VIC 3052, Australia. ${ }^{3}$ Centre for Drug Candidate Optimisation, Monash Institute of Pharmaceutical Sciences, Monash University, Parkville, VIC 3052, Australia. ${ }^{4}$ The Institute of Biochemistry and Biophysics, Polish Academy of Sciences, Warsaw, Poland. ${ }^{5}$ Elemental Bio-imaging Facility, The University of Technology Sydney, Broadway, Ultimo, NSW 2007, Australia. ${ }^{6}$ Australia Electron Microscope Unit, School of Biosciences, The University of Melbourne, Melbourne, VIC 3010, Australia. 'Bio21 Institute and Department of Pharmacology and Therapeutics, The University of Melbourne, Melbourne, VIC 3010, Australia.

Received: 15 May 2017 Accepted: 14 June 2017

Published online: 28 June 2017

\section{References}

1. Adlard PA, Cherny RA, Finkelstein DI, Gautier E, Robb E, Cortes M, Volitakis I, Liu X, Smith JP, Perez K et al (2008) Rapid restoration of cognition in Alzheimer's transgenic mice with 8-hydroxy quinoline analogs is associated with decreased interstitial Abeta. Neuron 59:43-55

2. Adlard PA, Bica L, White AR, Nurjono M, Filiz G, Crouch PJ, Donnelly PS, Cappai R, Finkelstein DI, Bush Al (2011) Metal ionophore treatment restores dendritic spine density and synaptic protein levels in a mouse model of Alzheimer's disease. PLoS One 6:e17669. doi:10.1371/journal.pone.0017669

3. Aisen P, Leibman A, Zweier J (1978) Stoichiometric and site characteristics of the binding of iron to human transferrin. J Biol Chem 253:1930-1937

4. Ayton S, Lei P, Duce JA, Wong BX, Sedjahtera A, Adlard PA, Bush Al, Finkelstein DI (2013) Ceruloplasmin dysfunction and therapeutic potential for Parkinson disease. Ann Neurol 73:554-559. doi:10.1002/ana.23817

5. Ayton S, Lei P, Hare DJ, Duce JA, George JL, Adlard PA, McLean C, Rogers JT, Cherny RA, Finkelstein DI et al (2015) Parkinson's disease iron deposition caused by nitric oxide-induced loss of beta-amyloid precursor protein. J Neurosci 35:3591-3597. doi:10.1523/JNEUROSCI.3439-14.2015

6. Ayton S, Lei P, McLean C, Bush Al, Finkelstein DI (2016) Transferrin protects against Parkinsonian neurotoxicity and is deficient in Parkinson's substantia nigra. Signal Transduction and Targeted Therapy 1:16015. doi:10.1038/ sigtrans.2016.15 
7. Barnham KJ, Bush Al (2008) Metals in Alzheimer's and Parkinson's diseases. Curr Opin Chem Biol 12:222-228 S1367-5931(08)00041-0. doi:10.1016/j.cbpa. 2008.02.019

8. Barnham KJ, Bush Al (2014) Biological metals and metal-targeting compounds in major neurodegenerative diseases. Chem Soc Rev 43:6727-6749. doi:10.1039/c4cs00138a

9. Belaidi AA, Bush Al (2016) Iron neurochemistry in Alzheimer's disease and Parkinson's disease: targets for therapeutics. J Neurochem 139(Suppl 1):179-197. doi:10.1111/jnc.13425

10. Berg D, Gerlach M, Youdim MB, Double KL, Zecca L, Riederer P, Becker G (2001) Brain iron pathways and their relevance to Parkinson's disease. J Neurochem 79:225-236

11. Berg D, Youdim MB, Riederer P (2004) Redox imbalance. Cell Tissue Res 318: 201-213. doi:10.1007/s00441-004-0976-5

12. Billings $\mathrm{J}$, Hare DJ, Nurjono M, Volitakis I, Cherny RA, Bush Al, Adlard PA, Finkelstein DI (2016) Effects of neonatal iron feeding and chronic Clioquinol administration on the Parkinsonian human A53T transgenic mouse. ACS Chem Neurosci 7:360-366. doi:10.1021/acschemneuro.5b00305

13. Bjorkblom B, Adilbayeva A, Maple-Grodem J, Piston D, Okvist M, Xu XM, Brede C, Larsen JP, Moller SG (2013) Parkinson disease protein DJ-1 binds metals and protects against metal-induced cytotoxicity. J Biol Chem 288: 22809-22820. doi:10.1074/jbc.M113.482091

14. Cabin DE, Gispert-Sanchez S, Murphy D, Auburger G, Myers RR, Nussbaum RL (2005) Exacerbated synucleinopathy in mice expressing A53T SNCA on a SNCA null background. Neurobiol Aging 26:25-35. doi:10.1016/j. neurobiolaging.2004.02.026

15. Cappai R, Leck SL, Tew DJ, Williamson NA, Smith DP, Galatis D, Sharples RA, Curtain CC, Ali FE, Cherny RA et al (2005) Dopamine promotes alphasynuclein aggregation into SDS-resistant soluble oligomers via a distinct folding pathway. FASEB J 19:1377-1379. doi:10.1096/fj.04-3437fje

16. Castellani RJ, Siedlak SL, Perry G, Smith MA (2000) Sequestration of iron by Lewy bodies in Parkinson's disease. Acta Neuropathol 100:111-114

17. Castro-Hernandez J, Adlard PA, Finkelstein DI (2017) Pramipexole restores depressed transmission in the ventral hippocampus following MPTP-lesion. Sci Rep 7:44426. doi:10.1038/srep44426

18. Cherny RA, Ayton S, Finkelstein DI, Bush Al, McColl G, Massa SM (2012) PBT2 reduces toxicity in a C. elegans model of polyQ aggregation and extends lifespan, reduces Striatal atrophy and improves motor performance in the R6/2 mouse model of Huntington's disease. J Huntingtons Dis 1:211-219. doi:10.3233/JHD-120029

19. Cole NB, Murphy DD, Lebowitz J, Di Noto L, Levine RL, Nussbaum RL (2005) Metal-catalyzed oxidation of alpha-synuclein: helping to define the relationship between oligomers, protofibrils, and filaments. J Biol Chem 280: 9678-9690

20. Danzer KM, Krebs SK, Wolff M, Birk G, Hengerer B (2009) Seeding induced by alpha-synuclein oligomers provides evidence for spreading of alphasynuclein pathology. J Neurochem 111:192-203. doi:10.1111/j.1471-4159. 2009.06324.x

21. Daugherty AM, Haacke EM, Raz N (2015) Striatal iron content predicts its shrinkage and changes in verbal working memory after two years in healthy adults. J Neurosci 35:6731-6743. doi:10.1523/JNEUROSCI.4717-14.2015

22. Davies P, Moualla D, Brown DR (2011) Alpha-synuclein is a cellular ferrireductase. PLoS One 6:e15814. doi:10.1371/journal.pone.0015814

23. Deas E, Cremades N, Angelova PR, Ludtmann MH, Yao Z, Chen S, Horrocks MH, Banushi B, Little D, Devine MJet al (2016) Alpha-Synuclein Oligomers Interact with Metal lons to Induce Oxidative Stress and Neuronal Death in Parkinson's Disease. Antioxid Redox Signal 24: 376-391. doi:10.1089/ars. 2015.6343

24. Devos D, Moreau C, Devedjian JC, Kluza J, Petrault M, Laloux C, Jonneaux A Ryckewaert G, Garcon G, Rouaix Net al (2014) Targeting chelatable iron as a therapeutic modality in Parkinson's disease. Antioxid Redox Signal 21: 195-210. doi:10.1089/ars.2013.5593

25. Dexter DT, Carayon A, Javoy-Agid F, Agid Y, Wells FR, Daniel SE, Lees AJ, Jenner P, Marsden CD (1991) Alterations in the levels of iron, ferritin and other trace metals in Parkinson's disease and other neurodegenerative diseases affecting the basal ganglia. Brain 114(Pt 4):1953-1975

26. Donovan A, Lima CA, Pinkus JL, Pinkus GS, Zon LI, Robine S, Andrews NC (2005) The iron exporter ferroportin/Slc40a1 is essential for iron homeostasis. Cell Metab 1:191-200. doi:10.1016/j.cmet.2005.01.003

27. Faucheux BA, Martin ME, Beaumont C, Hunot S, Hauw JJ, Agid Y, Hirsch EC (2002) Lack of up-regulation of ferritin is associated with sustained iron regulatory protein-1 binding activity in the substantia nigra of patients with Parkinson's disease. J Neurochem 83:320-330

28. Febbraro F, Giorgi M, Caldarola S, Loreni F, Romero-Ramos M (2012) Alpha-Synuclein expression is modulated at the translational level by iron. Neuroreport 23:576-580. doi:10.1097/WNR.0b013e328354a1f0

29. Finkelstein DI, Stanic D, Parish CL, Tomas D, Dickson K, Horne MK (2000) Axona sprouting following lesions of the rat substantia nigra. Neuroscience 97:99-112

30. Finkelstein DI, Stanic D, Parish CL, Drago J, Horne MK (2004) Quantified assessment of terminal density and innervation. Curr Protoc Neurosci Chapter 1: Unit 1 13. doi:10.1002/0471142301.ns0113s27

31. Finkelstein DI, Hare DJ, Billings JL, Sedjahtera A, Nurjono M, Arthofer E, George S, Culvenor JG, Bush Al, Adlard PA (2016) Clioquinol improves cognitive, motor function, and microanatomy of the alpha-Synuclein hA53T transgenic mice. ACS Chem Neurosci 7:119-129. doi:10.1021/acschemneuro.5b00253

32. Fleming SM, Salcedo J, Hutson CB, Rockenstein E, Masliah E, Levine MS, Chesselet MF (2006) Behavioral effects of dopaminergic agonists in transgenic mice overexpressing human wildtype alpha-synuclein. Neuroscience 142:1245-1253

33. Follmer C, Coelho-Cerqueira E, Yatabe-Franco DY, Araujo GD, Pinheiro AS, Domont GB, Eliezer D (2015) Oligomerization and membrane-binding properties of covalent adducts formed by the interaction of alpha-Synuclein with the toxic dopamine metabolite 3,4-Dihydroxyphenylacetaldehyde (DOPAL). J Biol Chem 290:27660-27679. doi:10.1074/jbc.M115.686584

34. Gans P, Sabatini A, Vacca A (1996) Investigation of equilibria in solution. Determination of equilibrium constants with the HYPERQUAD suite of programs. Talanta 43:1739-1753. doi:10.1016/0039-9140(96)01958-3

35. Giasson BI, Duda JE, Quinn SM, Zhang B, Trojanowski JQ, Lee VM (2002) Neuronal alpha-synucleinopathy with severe movement disorder in mice expressing A53T human alpha-synuclein. Neuron 34:521-533

36. Goodwill KE, Sabatier C, Stevens RC (1998) Crystal structure of tyrosine hydroxylase with bound cofactor analogue and iron at 2.3 a resolution: self-hydroxylation of Phe300 and the pterin-binding site. Biochemistry 37: 13437-13445. doi:10.1021/bi981462g

37. Guzman JN, Sanchez-Padilla J, Wokosin D, Kondapalli J, Ilijic E, Schumacker PT, Surmeier DJ (2010) Oxidant stress evoked by pacemaking in dopaminergic neurons is attenuated by DJ-1. Nature 468:696-700. doi:10.1038/nature09536

38. Hare D, Reedy B, Grimm R, Wilkins S, Volitakis I, George JL, Cherny RA, Bush Al, Finkelstein DI, Doble P (2009) Quantitative elemental bio-imaging of Mn, $\mathrm{Fe}, \mathrm{cu}$ and $\mathrm{Zn}$ in 6-hydroxydopamine induced parkinsonism mouse models. Metallomics 1:53-58

39. Hare DJ, Lee JK, Beavis AD, van Gramberg A, George J, Adlard PA, Finkelstein DI, Doble PA (2012) Three-dimensional atlas of iron, copper, and zinc in the mouse cerebrum and brainstem. Anal Chem 84:3990-3997. doi:10.1021/ac300374x

40. Hare DJ, Lei P, Ayton S, Roberts BR, Grimm R, George JL, Bishop DP, Beavis AD, Donovan SJ, Mc Coll G et al (2014) An iron-dopamine index predicts risk of parkinsonian neurodegeneration in the substantia nigra pars compacta. Chem Sci 5:2160-2169. doi:10.1039/c3sc53461h

41. Hare DJ, Lei P, Ayton S, Roberts BR, Grimm R, George JL, Bishop DP, Beavis AD, Donovan SJ, Mc Coll G et al (2014) An iron-dopamine index predicts risk of parkinsonian neurodegeneration in the substantia nigra pars compacta. Chem Sci 5:2160-2169. doi:10.1039/c3sc53461h

42. He Q, Song N, Xu H, Wang R, Xie J, Jiang H (2011) Alpha-synuclein aggregation is involved in the toxicity induced by ferric iron to SK-N-SH neuroblastoma cells. J Neural Transm (Vienna) 118:397-406. doi:10.1007/s00702-010-0453-0

43. Hillmer AS, Putcha P, Levin J, Hogen T, Hyman BT, Kretzschmar H, McLean PJ, Giese A (2010) Converse modulation of toxic alphasynuclein oligomers in living cells by N'-benzylidene-benzohydrazide derivates and ferric iron. Biochem Biophys Res Commun 391:461-466. doi:10.1016/j.bbrc.2009.11.080

44. Hung LW, Villemagne VL, Cheng L, Sherratt NA, Ayton S, White AR, Crouch PJ, Lim S, Leong SL, Wilkins Set al (2012) The hypoxia imaging agent Cull(atsm) is neuroprotective and improves motor and cognitive functions in multiple animal models of Parkinson's disease. J Exp Med 209: 837-854. doi:10.1084/jem.20112285

45. Hwang DY, Fleming SM, Ardayfio P, Moran-Gates T, Kim H, Tarazi FI, Chesselet MF, Kim KS (2005) 3,4-dihydroxyphenylalanine reverses the motor deficits in Pitx3-deficient aphakia mice: behavioral characterization of a novel genetic model of Parkinson's disease. J Neurosci 25:2132-2137. doi:10. 1523/JNEUROSCI.3718-04.2005 
46. Irving $H$, Miles $M$, Pettit $L$ (1967) A study of some problems in determining the stoicheiometric proton dissociation constants of complexes by potentiometric titrations using a glass electrode. Anal Chim Acta 38:475-488

47. Jackson-Lewis V, Przedborski S (2007) Protocol for the MPTP mouse model of Parkinson's disease. Nat Protoc 2:141-151. doi:10.1038/nprot.2006.342

48. Jackson-Lewis V, Jakowec M, Burke RE, Przedborski S (1995) Time course and morphology of dopaminergic neuronal death caused by the neurotoxin 1-methyl-4-phenyl-1,2,3,6-tetrahydropyridine. Neurodegeneration 4:257-269

49. Jakowec MW, Petzinger GM (2004) 1-methyl-4-phenyl-1,2,3,6tetrahydropyridine-lesioned model of parkinson's disease, with emphasis on mice and nonhuman primates. Comp Med 54:497-513

50. Jakowec MW, Nixon K, Hogg E, McNeill T, Petzinger GM (2004) Tyrosine hydroxylase and dopamine transporter expression following 1-methyl-4phenyl-1,2,3,6-tetrahydropyridine-induced neurodegeneration of the mouse nigrostriatal pathway. J Neurosci Res 76:539-550. doi:10.1002/jnr.20114

51. Jeon BS, Jackson-Lewis $V$, Burke RE (1995) 6-Hydroxydopamine lesion of the rat substantia nigra: time course and morphology of cell death. Neurodegeneration 4:131-137

52. Kang JH, Irwin DJ, Chen-Plotkin AS, Siderowf A, Caspell C, Coffey CS, Waligorska T, Taylor P, Pan S, Frasier Met al (2013) Association of cerebrospinal fluid beta-amyloid 1-42, T-tau, P-tau181, and alphasynuclein levels with clinical features of drug-naive patients with early Parkinson disease. JAMA Neurol 70: 1277-1287. doi:10.1001/jamaneurol. 2013.3861

53. Kaur D, Yantiri F, Rajagopalan S, Kumar J, Mo JQ, Boonplueang R, Viswanath V, Jacobs R, Yang L, Beal MF et al (2003) Genetic or pharmacological iron chelation prevents MPTP-induced neurotoxicity in vivo: a novel therapy for Parkinson's disease. Neuron 37:899-909

54. Kaur D, Rajagopalan S, Andersen JK (2009) Chronic expression of $\mathrm{H}$ ferritin in dopaminergic midbrain neurons results in an age-related expansion of the labile iron pool and subsequent neurodegeneration: implications for Parkinson's disease. Brain Res 1297:17-22. doi:10.1016/j. brainres.2009.08.043

55. Kline MA, Orvig C (1992) Complexation of iron with the orally active decorporation drug L1 (3-hydroxy-1,2-dimethyl-4-pyridinone). Clin Chem 38:562-565

56. Lan J, Jiang DH (1997) Desferrioxamine and vitamin E protect against iron and MPTP-induced neurodegeneration in mice. J Neural Transm (Vienna) 104:469-481. doi:10.1007/BF01277665

57. Lannfelt L, Blennow K, Zetterberg H, Batsman S, Ames D, Harrison J, Masters CL, Targum S, Bush Al, Murdoch R et al (2008) Safety, efficacy, and biomarker findings of PBT2 in targeting Abeta as a modifying therapy for Alzheimer's disease: a phase lla, double-blind, randomised, placebo-controlled trial. Lancet Neurol 7:779-786. doi:10.1016/S1474-4422(08)70167-4

58. Lear J, Hare D, Adlard P, Finkelstein D, Doble P (2012) Improving acquisition times of elemental bio-imaging for quadrupole-based LA-ICP-MS. J Anal At Spectrom 27:159-164

59. Lear J, Hare DJ, Fryer F, Adlard PA, Finkelstein DI, Doble PA (2012) Highresolution elemental bioimaging of $\mathrm{Ca}, \mathrm{Mn}, \mathrm{Fe}, \mathrm{CO}, \mathrm{Cu}$, and $\mathrm{Zn}$ employing LA-ICP-MS and hydrogen reaction gas. Anal Chem 84:6707-6714. doi:10. 1021/ac301156f

60. Lee DW, Rajagopalan S, Siddiq A, Gwiazda R, Yang L, Beal MF, Ratan RR, Andersen JK (2009) Inhibition of prolyl hydroxylase protects against 1-methyl-4-phenyl-1,2,3,6-tetrahydropyridine-induced neurotoxicity: model for the potential involvement of the hypoxia-inducible factor pathway in Parkinson disease. J Biol Chem 284:29065-29076. doi:10.1074/jbc.M109.000638

61. Lei P, Ayton S, Finkelstein DI, Spoerri L, Ciccotosto GD, Wright DK, Wong BX, Adlard PA, Cherny RA, Lam LQ et al (2012) Tau deficiency induces parkinsonism with dementia by impairing APP-mediated iron export. Nat Med 18:291-295. doi:10.1038/nm.2613

62. Lei P, Ayton S, Moon S, Zhang Q, Volitakis I, Finkelstein DI, Bush Al (2014) Motor and cognitive deficits in aged tau knockout mice in two background strains. Mol Neurodegener 9:29. doi:10.1186/1750-1326-9-29

63. Leong SL, Pham CL, Galatis D, Fodero-Tavoletti MT, Perez K, Hill AF, Masters CL, Ali FE, Barnham KJ, Cappai R (2009) Formation of dopamine-mediated alpha-synuclein-soluble oligomers requires methionine oxidation. Free Radic Biol Med 46:1328-1337. doi:10.1016/j.freeradbiomed.2009.02.009

64. Lhermitte J, Kraus WM, McAlpine D (1924) On the occurrence of abnormal deposits of iron in the brain in parkinsonism with special reference to its location. J Neurol Psychopathol 5:195-208
65. Liu L, Hsu SS, Kalia SK, Lozano AM (2003) Injury and strain-dependent dopaminergic neuronal degeneration in the substantia nigra of mice after axotomy or MPTP. Brain Res 994:243-252

66. Martin LJ, Pan Y, Price AC, Sterling W, Copeland NG, Jenkins NA, Price DL, Lee MK (2006) Parkinson's disease alpha-synuclein transgenic mice develop neuronal mitochondrial degeneration and cell death. J Neurosci 26:41-50

67. Matsuura K, Kabuto H, Makino H, Ogawa N (1997) Pole test is a useful method for evaluating the mouse movement disorder caused by striatal dopamine depletion. J Neurosci Methods 73:45-48

68. Medeiros MS, Schumacher-Schuh A, Cardoso AM, Bochi GV, Baldissarelli J, Kegler A, Santana D, Chaves CM, Schetinger MR, Moresco RNet al (2016) Iron and oxidative stress in Parkinson's disease: an observational study of injury biomarkers. PLoS One 11: e0146129. doi:10.1371/journal.pone.0146129

69. Meredith GE, Kang UJ (2006) Behavioral models of Parkinson's disease in rodents: a new look at an old problem. Mov Disord 21:1595-1606. doi:10.1002/mds.21010

70. Morris CM (2011) Any old iron? Brain 134:924-927. doi:10.1093/brain/awr056

71. Oakley AE, Collingwood JF, Dobson J, Love G, Perrott HR, Edwardson JA, Elstner M, Morris CM (2007) Individual dopaminergic neurons show raised iron levels in Parkinson disease. Neurology 68:1820-1825

72. Oaks AW, Frankfurt M, Finkelstein DI, Sidhu A (2013) Age-dependent effects of A53T alpha-synuclein on behavior and dopaminergic function. PLoS One 8:e60378. doi:10.1371/journal.pone.0060378

73. Ogawa N, Hirose Y, Ohara S, Ono T, Watanabe Y (1985) A simple quantitative bradykinesia test in MPTP-treated mice. Res Commun Chem Pathol Pharmacol 50:435-441

74. Opazo C, Huang X, Cherny RA, Moir RD, Roher AE, White AR, Cappai R, Masters CL, Tanzi RE, Inestrosa NC et al (2002) Metalloenzyme-like activity of Alzheimer's disease beta-amyloid. Cu-dependent catalytic conversion of dopamine, cholesterol, and biological reducing agents to neurotoxic H(2)O(2). J Biol Chem 277:40302-40308. doi:10.1074/jbc.M206428200

75. Origa R, Bina P, Agus A, Crobu G, Defraia E, Dessi C, Leoni G, Muroni PP, Galanello R (2005) Combined therapy with deferiprone and desferrioxamine in thalassemia major. Haematologica 90:1309-1314

76. Orth ES, Medeiros M, Bortolotto T, Terenzi H, Kirby AJ, Nome F (2011) Dephosphorylation reactions with deferoxamine, a potential chemical nuclease. The Journal of organic chemistry 76:10345-10348. doi:10.1021/ jo202074y

77. Parish CL, Finkelstein DI, Drago J, Borrelli E, Horne MK (2001) The role of dopamine receptors in regulating the size of axonal arbors. J Neurosci 21: 5147-5157

78. Paul BD, Sbodio Jl, Xu R, Vandiver MS, Cha JY, Snowman AM, Snyder SH (2014) Cystathionine gamma-lyase deficiency mediates neurodegeneration in Huntington's disease. Nature 509:96-100. doi:10.1038/nature13136

79. Purisai MG, McCormack AL, Langston WJ, Johnston LC, Di Monte DA (2005) Alpha-synuclein expression in the substantia nigra of MPTP-lesioned nonhuman primates. Neurobiol Dis 20:898-906. doi:10.1016/j.nbd.2005.05.028

80. Raha AA, Vaishnav RA, Friedland RP, Bomford A, Raha-Chowdhury R (2013) The systemic iron-regulatory proteins hepcidin and ferroportin are reduced in the brain in Alzheimer's disease. Acta neuropathologica communications 1:55. doi:10.1186/2051-5960-1-55

81. Sajid R, Ghani F, Adil S, Khurshid M (2009) Oral iron chelation therapy with deferiprone in patients with Thalassemia major. J Pak Med Assoc 59:388-390

82. Schwarting RK, Huston JP (1996) The unilateral 6-hydroxydopamine lesion model in behavioral brain research. Analysis of functional deficits, recovery and treatments. Prog Neurobiol 50:275-331 S0301-0082(96)00040-8

83. Shendelman S, Jonason A, Martinat C, Leete T, Abeliovich A (2004) DJ-1 is a redox-dependent molecular chaperone that inhibits alpha-synuclein aggregate formation. PLoS Biol 2:e362. doi:10.1371/journal.pbio.0020362

84. Siddiq A, Ayoub IA, Chavez JC, Aminova L, Shah S, LaManna JC, Patton SM, Connor JR, Cherny RA, Volitakis I et al (2005) Hypoxia-inducible factor prolyl 4-hydroxylase inhibition. A target for neuroprotection in the central nervous system. J Biol Chem 280:41732-41743. doi:10.1074/jbc.M504963200

85. Sobotka TJ, Whittaker P, Sobotka JM, Brodie RE, Quander DY, Robl M, Bryant M, Barton CN (1996) Neurobehavioral dysfunctions associated with dietary iron overload. Physiol Behav 59:213-219

86. Tatton NA, Kish SJ (1997) In situ detection of apoptotic nuclei in the substantia nigra compacta of 1-methyl-4-phenyl-1,2,3,6-tetrahydropyridinetreated mice using terminal deoxynucleotidyl transferase labelling and acridine orange staining. Neuroscience 77:1037-1048 
87. Ungerstedt U (1976) 6-hydroxydopamine-induced degeneration of the nigrostriatal dopamine pathway: the turning syndrome. Pharmacol Ther B 2:37-40

88. Varcin M, Bentea E, Michotte Y, Sarre S (2012) Oxidative stress in genetic mouse models of Parkinson's disease. Oxidative Med Cell Longev 2012: 624925. doi:10.1155/2012/624925

89. Vila M, Vukosavic S, Jackson-Lewis V, Neystat M, Jakowec M, Przedborski S (2000) Alpha-synuclein up-regulation in substantia nigra dopaminergic neurons following administration of the parkinsonian toxin MPTP. J Neurochem 74:721-729

90. Zhang MY, Kagan N, Sung ML, Zaleska MM, Monaghan M (2008) Sensitive and selective liquid chromatography/tandem mass spectrometry methods for quantitative analysis of 1-methyl-4-phenyl pyridinium (MPP+) in mouse striatal tissue. J Chromatogr B Analyt Technol Biomed Life Sci 874:51-56. doi:10.1016/j.jchromb.2008.08.030

91. Zhou W, Zhu M, Wilson MA, Petsko GA, Fink AL (2006) The oxidation state of DJ-1 regulates its chaperone activity toward alpha-synuclein. J Mol Biol 356:1036-1048. doi:10.1016/j.jmb.2005.12.030

92. Zhou W, Milder JB, Freed CR (2008) Transgenic mice overexpressing tyrosine-to-cysteine mutant human alpha-synuclein: a progressive neurodegenerative model of diffuse Lewy body disease. J Biol Chem 283:9863-9870

\section{Submit your next manuscript to BioMed Central} and we will help you at every step:

- We accept pre-submission inquiries

- Our selector tool helps you to find the most relevant journal

- We provide round the clock customer support

- Convenient online submission

- Thorough peer review

- Inclusion in PubMed and all major indexing services

- Maximum visibility for your research

Submit your manuscript at www.biomedcentral.com/submit 